\title{
Bioconversion Process of Barley Crop Residues into Biogas-Energetic-Environmental Potential in Spain
}

\author{
Carlos Morales-Polo ${ }^{1,2,3, *(\mathbb{D})}$, María del Mar Cledera-Castro ${ }^{1,2,3}$ (D), Marta Revuelta-Aramburu ${ }^{2}$ \\ and Katia Hueso-Kortekaas ${ }^{2}$ \\ 1 Institute for Research in Technology, Comillas Pontifical University, 28015 Madrid, Spain; \\ mcledera@comillas.edu \\ 2 Department of Mechanical Engineering, ICAI School of Engineering, Comillas Pontifical University, \\ 28015 Madrid, Spain; mrevuara@comillas.edu (M.R.-A.); khueso@comillas.edu (K.H.-K.) \\ 3 Rafael Mariño Chair for New Energy Technology, Comillas Pontifical University, 28015 Madrid, Spain \\ * Correspondence: cmorales@comillas.edu; Tel.: 34-91-542-28-00
}

check for

updates

Citation: Morales-Polo, C.;

Cledera-Castro, M.d.M.;

Revuelta-Aramburu, M.;

Hueso-Kortekaas, K. Bioconversion

Process of Barley Crop Residues into Biogas-Energetic-Environmental

Potential in Spain. Agronomy 2021, 11, 640. https://doi.org/10.3390/

agronomy 11040640

Academic Editor: Carlos Martín

Received: 5 February 2021

Accepted: 23 March 2021

Published: 26 March 2021

Publisher's Note: MDPI stays neutral with regard to jurisdictional claims in published maps and institutional affiliations.

Copyright: (C) 2021 by the authors. Licensee MDPI, Basel, Switzerland. This article is an open access article distributed under the terms and conditions of the Creative Commons Attribution (CC BY) license (https:/ / creativecommons.org/licenses/by/ $4.0 /)$.

\begin{abstract}
Barley fields reach 1.7 million hectares in Spain, of which 320,000 are used to produce malt, generating 450,000 tons of crop residue from barley intended for malt production. One way to treat this waste in an environmentally sound, energy-sustainable and economically cost-effective manner is anaerobic digestion. The biogas generated can be used as fuel and as a renewable source of energy (providing a solution to the energy supply problem from an environmental point of view). It has been shown that, when treated along with sludge from a Upflow Anaerobic Sludge Blanket (UASB) reactor, the crop malt residue produces about $1604 \mathrm{NmL}$ of biogas per $100 \mathrm{~g}$; with a content in methane of $27.486 \%$. The development of the process has been studied with a novel indicator, hydrogen generation, and it has been determined that the process takes place in two phases. It has been demonstrated that this solution is beginning to be energy-efficient and therefore to produce energy for external uses in regions that have at least 6000 hectares of planted barley. At best, it can be considered, in a given region, the equivalent of a $115 \mathrm{MW}$ power plant. It could supply energy to 10 thousand homes per year. Therefore, it is considered an energy-efficient solution that com-plies with the Sustainable Development Goals \#1,\#7,\#10,\#12 and \#13. It guarantees access to energy in isolated areas or with supply problems, and results in a $55.4 \%$ reduction in emissions of equivalent- $\mathrm{CO}_{2}$ (which equals 38,060 tons of equivalent- $\mathrm{CO}_{2}$ in Spain).
\end{abstract}

Keywords: barley crop residue; biochemical methane potential; material degradability; anaerobic indicators; biogas feasibility; biogas emissions

\section{Introduction}

Agri-food trade in the European Union (EU) is one of the most important in the world economy [1]. In 2019, the EU positioned itself as the world's largest exporter and the second largest importer of agri-food products. The value of exports increased to 14.7 billion euros in 2019 compared to 2018, while import values increased to 10.7 billion euros [2]. Both imports and exports have been growing since 2002, contributing to a monthly trade surplus in the agri-food sector of 4.0 billion euros.

According to EUROSTAT data, the demographic situation in the EU reflects an upward growth; since 2008, the population has increased by 13 million inhabitants [3]. Alongside this population growth, an increase in needs and consumption is associated, especially in the agri-food sector, given the basic need for population feeding, but also in the energy field, as discussed below.

The agri-food industry comprises activities from all economic sectors [1]. The food supply chain (FSC) begins with stages of the primary sector (agriculture and livestock), which generates by-products (i.e., manure, waffle, cornstalk) and food waste and food loss in the form of low-quality products, damaged production, or products with no commercial 
value [4,5]. In response to the first part of FSC, and primary sector activities, the main crop in the EU is cereal (including rice), which in 2018 was 295.1 million tons, corresponding to $11.3 \%$ of global production [6]. That is why cereal production is particularly influential at European level. In Spain, one of the main producers of the agricultural sector in Europe, an average of 6 million hectares of cereals are grown These are distributed in 38.7\% corresponding to barley, $28.9 \%$ soft wheat, $15.8 \%$ maize, $6.2 \%$ oat, $5.7 \%$ for durum wheat, $2.9 \%$ triticale, $1.7 \%$ rye and $0.1 \%$ sorghum [7].

Agricultural activities, as well as livestock and forestry activities, generate in their various stages variable quantities of by-products and waste whose storage, disposal or disposal represents an additional task and source of costs for the producer [8], as well as constituting an environmental problem by the increasing generation of waste associated with human consumption and population growth. These wastes are considered an underutilized source of resources as they are produced continuously and renewably [9]. These residues are, in a very small part, partially valued at different levels (production of biofuel, food and animal bed, composting or building materials) [10]; however, a significant volume of them is not reused and constitutes a serious problem that negatively affects the overall sustainability of the agricultural sector [10]. The agricultural waste known as industrial, those that must be eliminated because they are not usable in the area in which they are generated, are in the case of cereal and grain crops, straw [11]. In Spain, 35.7\% of all agricultural waste produced consists of residues from cereal crops (mostly barley, followed by wheat and maize), with annual quantities exceeding 9 million tons [12].

Within the production of barley in Spain, an important part is intended for its processing into malt. Malting is a process applied to cereal grains, by which they germinate by submerging them in water, then being quickly dried by injection of hot air. During this process, malted grains develop enzymes that convert grain starch into sugar. Barley is the most commonly used cereal for malting because of this reason [13].

According to the results of the authors, in Spain 320,000 hectares of barley are allocated to the production of malt. This means that $18.850 \%$ of barley production (See Section 3.10.1) is destined for this purpose and is therefore a potential source of straw waste generation, which can be harnessed in some way.

Taking up the problem of population growth previously introduced, it is also associated with an increase in energy consumption (Figure 1). This growth rate is expected to continue over time. In fact, the International Energy Outlook [14] predicts a 28\% increase in energy consumption for the period 2015-2040. Other agencies such as the International Energy Agency estimate this growth by 35\% for the period 2010-2035 [15]. Of all the energy consumed in Europe in 2017, approximately 80\% came from fossil sources [16] such as coal, oil, natural gas and derivatives. Finding new forms of energy to reduce this dependence on foreign and fossil fuels is strategic. Moreover, given that fossil fuels are known emitters of greenhouse gases, the reduction in their use is not only strategic, but also necessary. In fact, of the 4.66 gigatons of equivalent $\mathrm{CO}_{2}$ emitted by the EU, $82.8 \%$ of emissions came from the energy sector [16]. These two reasons mark the roadmap for a more renewable energy model [17].

Both growth in cereal consumption and production, as well as growth in energy consumption, lead to several environmental problems such as increased waste generation, and the possible increase in greenhouse emissions when fossil fuels are used for energy production [18]. A joint solution for both problems can be provided by Anaerobic Digestion (AD) [19]. Anaerobic digestion allows the bioconversion of the organic matter present in organic substrates, such as a residue, into biogas (a renewable energy source) via microbiological degradation [20]. AD also generates a digestate that can be used as fertilizer. In this way, an energy source is obtained by reducing the waste generated and it also creates a circular economy in that process, solving both environmental problems [21]. 


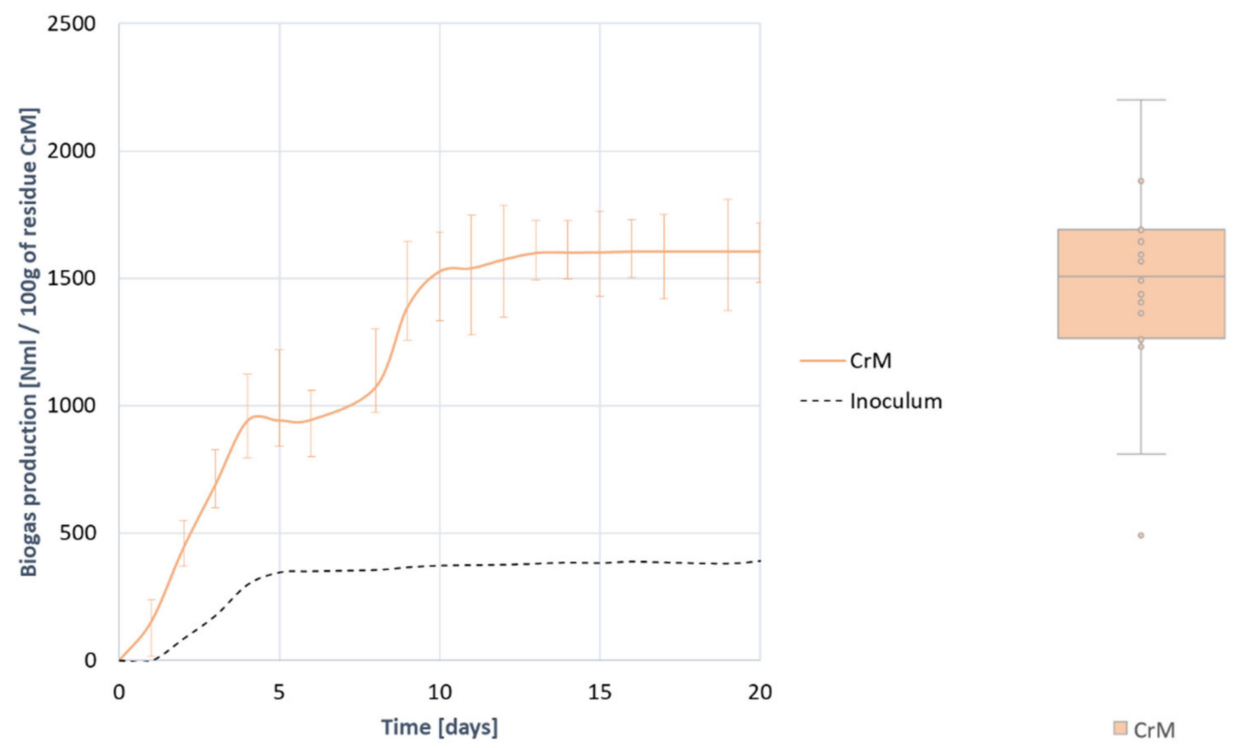

Figure 1. Gross biogas production mean curve from the anaerobic digestion of $100 \mathrm{~g}$ of residue (Crop Barley Residue) CrM, and box diagram of its variation.

$\mathrm{AD}$ is a very complex process in which different stages occur simultaneously with different microorganisms [22], each producing the substrates necessary for the next stage to take place, depending on the substrate composition. It is then important to perfectly know the composition of the substrate to be digested, so that the process development can be determined. In addition, because of the complexity of the AD process, in which different stages occur simultaneously with different microorganisms, a medium in which all influential parameters are controlled is required to ensure a stable environment [23]. One of the novelties of this study is the use as development of the process indicator, typical variables such as $\mathrm{pH}$ combined with the study of the evolution of the hydrogen content generated and consumed during the process. $\mathrm{H}_{2}$ is intermediate gas that marks with its appearance the beginning of the stages of hydrolysis, acidogenesis and acetogenesis, and with its reduction the development of methanogenesis since it is transformed into methane via hydrogenotrophic methanogenesis, so that monitoring its evolution can also monitor the development of the process.

For all of the above, the main objective of this research is to propose and study the feasibility and process development of treatment by anaerobic digestion of crop residues generated during harvest of barley that is intended for malt production (barley straw).

To this end, the substrate is completely characterized, the anaerobic digestion process is analyzed through all phases and processes, focusing on the inhibitions and alterations of the process and the potential for biogas and methane generation is determined. Finally, the amount of energy that can be obtained through this route is estimated, against with the reduction of equivalent $\mathrm{CO}_{2}$ emissions that comes when using this renewable energy source to replace a conventional energy source.

\section{Materials and Methods}

\subsection{Test Samples}

The studied substrate is the residue from barley intended for malt production, hereinafter CrM. To avoid variability in the composition of the substrate, a laboratory-generated residue was used. For this purpose, barley of the Hordeum distichon type was used, which undergoes a malting process, keeping the grains moist for 5 days, dried at $40{ }^{\circ} \mathrm{C}$ for $24 \mathrm{~h}$ and then at $60^{\circ} \mathrm{C}$ for one night.

As an inoculum, and therefore the source that provides methane-based and anaerobic biomass to trigger the biomethanization process, sewage sludge from a Wastewater Treatment 
Plant (WWTP) from Madrid, Spain. To perform the Biochemical Methane Potential (BMP) tests it is recommended to use a stable and easily accessible inoculum [24]. Fundamental standards such as UNE-EN ISO 11734 and VDI-4630 [25] recommend using sludge from WWTP. Several authors advise it because of its accessibility and permanence of biomass [26,27], including pioneers in conducting Biochemical Methane Potential (BMP) test in 1979 [28], the following pioneers in the conduct of BMP assays [29]. In particular, in this study it is a granular sludge from an Upflow Anaerobic Sludge Blanket (UASB) reactor, from an agri-food industry sewage treatment plant. This type of sludge, along with its granule agglomeration characteristic makes it resistant to internal or process alterations [30].

\subsection{Analytical Methods for Compositional Characterization of Samples, Inoculum and Mixture Introduced in the Reactor}

One of the sub-objectives of this research is to characterize the substrates in depth to know, draw conclusions and assist in the determination of the development of the process. For this purpose, the CrM substrate and the inoculum are characterized. In addition, the same compositional study is also performed to the mixture of substrate + inoculum introduced into the reactor, before the digestion test and after completion of the BMP test. In this way it can be compared and determined what changes in the composition has caused anaerobic digestion, such as how much organic matter has been degraded, whether the mixture has developed accumulation of (Volatile Fatty Acid) VFA, or how much volatile solids have been degraded.

In particular, the following compositional determinations according to the standardized methods were carried out (Table 1$)$.

\subsection{Biochemical Methane Potential Tests to Determine de Anaerobic Degradation}

The Biochemical Methane Potential (BMP) test procedure has been developed in accordance with UNE-EN ISO 11734 [31], including a gas chromatograph for the measurement of biogas composition. In order to determine the amount of methane produced the UNE-EN ISO 11734 [31] standard uses manometric methods. The VDI-4630 [25] procedure has been used to transform the measured pressure inside the reactor into the gas flow generated.

The test conditions were the same as those used on the full scale. Digestion is performed under mesophilic conditions, $37 \pm 1{ }^{\circ} \mathrm{C}$, with a ratio between substrate and inoculum of 1:3 m/v, that is, for $300 \mathrm{~mL}$ of UASB sludge, $100 \mathrm{~g}$ of CrM residue are added for digestion [25].

Pressure changes inside the reactor are measured daily. Also, a sample of the gas generated in the reactors is extracted daily and analyzed in a gas chromatograph to determine the proportion of methane and hydrogen in the biogas. An Agilent (California, USA) 7820A gas chromatograph (GC) was used with a thermal conductivity detector (TCD), equipped with a Molsieve 5A-CP molecular sieve, and a PoraPLOT Q capillary column. $\mathrm{N}_{2}$ is used as a carrier gas to detect $\mathrm{H}_{2}$ more easily. In addition, by using $\mathrm{N}_{2}$ as a gas to ensure air displacement and anaerobic conditions inside the bottles.

Twenty-one repetitions are made with the aim of obtaining reliable results with the least dispersion possible. Since the substrate is a lab prepared sample, there is no dispersion in the results due to it. The only dispersion variable is the inoculum, which, as discussed, is obtained from a UASB reactor from a WWTP. However, attempts have been made to minimize this dispersion by taking inoculum samples on the same days of the week, when the level of production was similar and the characterization of the inoculum too.

\subsection{Statistical Analysis of Results}

As the tests were repeated 21 times, a statistical analysis was necessary to determine the dispersion between them is so large that there is no relationship, an ANOVA statistical analysis with a 95\% confidence level is performed accompanied by their respective DMS and Tukey contrasts. The starting hypotheses are $\mathrm{HO}=$ Equality between curves, and $\mathrm{H} 1$ = Inequality between curves. 
Table 1. Standardized procedures used for compositional characterization of substrates and mixtures.

\begin{tabular}{|c|c|}
\hline & Method Procedure \\
\hline \multicolumn{2}{|l|}{ Physical parameters } \\
\hline $\begin{array}{l}\text { Humidity-Hum }[\% \text { wet weight }] \\
\text { Total Solids-TS [\% wet weight] } \\
\text { Volatile Solids-vs. [\% wet weight] }\end{array}$ & APHA 2540-G \\
\hline \multicolumn{2}{|l|}{ Macronutritional Analysis (LPCH Content) } \\
\hline $\begin{array}{l}\text { Lipids }(\mathrm{L})[\% \text { wet weight }] \\
\text { Proteins }(\mathrm{P})[\% \text { wet weight }] \\
\text { Carbohydrates }(\mathrm{CH})[\% \text { wet weight }]\end{array}$ & UNE-EN-ISO 13804:2013 \\
\hline \multicolumn{2}{|c|}{ Organic Content Analysis (Chemical Oxygen Demand COD) } \\
\hline $\begin{array}{l}\text { Total COD-CODt }\left[\mathrm{mg} \mathrm{O}_{2} / \mathrm{g}-\mathrm{mL}\right] \\
\text { Filtered COD-CODf }\left[\mathrm{mg} \mathrm{O}_{2} / \mathrm{g}-\mathrm{mL}\right] \\
\text { Solubility [\%] }\end{array}$ & APHA 5220-B \\
\hline \multicolumn{2}{|l|}{ Nitrogen Content Analysis } \\
\hline $\begin{array}{l}\text { Total Kjeldahl Nitrogen-TKN }[\mathrm{mg} \mathrm{N} / \mathrm{g}-\mathrm{mL}] \\
\text { Amoniacal Nitrogen-AN }[\mathrm{mg} \mathrm{N} / \mathrm{g}-\mathrm{mL}] \\
\text { Organic Nitrogen-ON [mg N/g-mL] }\end{array}$ & $\begin{array}{l}\text { APHA } 4500-\mathrm{N} \\
\text { APHA } 4500-\mathrm{NH}_{3} \\
\text { APHA } 4500-\mathrm{N}_{\text {org }}\end{array}$ \\
\hline \multicolumn{2}{|l|}{$\mathrm{pH}$ and Alkalinity Analysis } \\
\hline $\begin{array}{l}\mathrm{pH} \\
\text { Total Alkalinity-TA }\left[\mathrm{mg} \mathrm{CaCO}_{3} / \mathrm{g}-\mathrm{mL}\right] \\
\text { Partial Alkalinity-PA }\left[\mathrm{mg} \mathrm{CaCO}_{3} / \mathrm{g}-\mathrm{mL}\right] \\
\text { Intermediate Alkalinity-IA }[\mathrm{mg} \\
\left.\mathrm{CaCO}_{3} / \mathrm{g}-\mathrm{mL}\right]\end{array}$ & APHA 2320-B \\
\hline Elemental Analysis & \\
\hline $\begin{array}{l}\mathrm{C}[\% \text { dry weight }] \\
\mathrm{H}[\% \text { dry weight }] \\
\mathrm{N}[\% \text { dry weight }] \\
\mathrm{S}[\% \text { dry weight }]\end{array}$ & UNE-EN-ISO 15104:2011 \\
\hline
\end{tabular}

Some descriptive statistics are also calculated to help determine the level of dispersion between the results. For this purpose, a visual method is used using box diagrams and a quantitative method through Analysis of the Coefficient of Variation (CV).

\subsection{Mathematical Adjustment and Determinations of Results}

Once the results are obtained these are treated mathematically. Methane generation curves are treated as first-order kinetics, according to the described process by Veeken and Hamlers [32]. The disintegration constant $\left(\mathrm{k}_{\mathrm{dis}}\right)$ can be obtained directly by considering the complete anaerobic digestion process, giving information about the depth and speed of the hydrolysis process. Also, maximum amount of actual methane obtained in the process $\left(\mathrm{CH}_{4 \max }\right)$ can be determined, adjusting the generation data by means of least squares, to a first order kinetics reaction:

$$
\mathrm{CH}_{4}(\mathrm{t})=\mathrm{CH}_{4} \max \cdot\left[1-\mathrm{e}^{-\mathrm{k}_{\mathrm{dis}} \cdot \mathrm{t}}\right],
$$

where $\mathrm{CH}_{4}(\mathrm{t})$ represents the production of methane on the $\mathrm{t}$-day; $\mathrm{CH}_{4 \max }$ the maximum generation of methane recorded (which can be assumed by the latest generation); and $\mathrm{k}_{\mathrm{dis}}$ the average disintegration constant measured in days ${ }^{-1}$. 
The theoretical generation of methane that was to be expected after anaerobic degradation of the substrate can be obtained from the reduction of COD experienced before and after the BMP test.

$$
\mathrm{V}_{\text {theoretical } \mathrm{CH}_{\text {accumulated }}}[\mathrm{Nml}]=\frac{\left(\mathrm{COD}_{0}-\mathrm{COD}_{\mathrm{f}}\right) \cdot \mathrm{V}_{\text {test }} \cdot 340}{1000} \cdot \frac{1}{0.9869},
$$

where $\mathrm{COD}_{0}$ and $\mathrm{COD}_{\mathrm{f}}$ represents the COD levels measured at baseline at the end of the BMP test expressed in $\mathrm{mg} / \mathrm{l} ; \mathrm{V}_{\text {test }}$ the test volume occupied by the mixture substrate + sludge expressed in litters; 340 the conversion factor of COD in methane; and 1/0.9869 the conversion factor from standard conditions $\left(0^{\circ} \mathrm{C}\right.$ and 1 bar $)$ to normal conditions $\left(0^{\circ} \mathrm{C}\right.$ and $1 \mathrm{~atm})$.

The level of degradation of the substrate or residue can be calculated analytically through the COD reduction degradation levels and provides information about the level of the degradation of the substrate, regardless of degradation inoculum.

$$
\mathrm{BD}_{\text {residue }}[\%]=\frac{\left(\mathrm{COD}_{\text {mixture }_{0}}-\mathrm{COD}_{\text {sludge }_{0}}\right)-\left(\mathrm{COD}_{\text {mixture }_{\mathrm{f}}}-\mathrm{COD}_{\text {sludge }_{\mathrm{f}}}\right)}{\left(\mathrm{COD}_{\text {mixture }_{0}}-\mathrm{COD}_{\text {sludge }_{0}}\right)} \cdot 100
$$

\subsection{Energy Suitability of the Proposed Process: Energy Balance Analysis}

One of the objectives to be covered by this research is to determine whether the proposed solution (anaerobic treatment of barley crop residues) is highly cost-effective. To do this, it analyses its potential, taking into account the energy generated in form of biogas, the needs that must be met in the process, and whether there is energy available for external uses.

The procedure has been developed according to the one described by the authors in the article [33], which in turn is based on the one described in [19]. Firstly, analyses and calculates the energy needs of the anaerobic process. Subsequently, with the laboratory data obtained in this research calculates the energy available in the biogas generated, depending on the amount of biogas that is produced and its methane content. Finally, it is determined whether net energy available for external uses exists or not, once the needs of the process (heat demand and electricity demand) have been met, for example for supply in the residential sector. In this way, if net available energy exists, the process would be considered as energy efficient.

2.7. Environmental Suitability of the Proposed Process: Emissions Reduction by Using Generated Biogas as an Energy Source Rather Than a Conventional Fossil Fuel

The objective of this section is to estimate the reduction in emissions that would occur if it is decided to use the biogas generated in the proposed solution as an energy source, rather than obtaining such energy by conventional means in the combustion of a fossil fuel. To this end, the "Methodology for thermal energy projects aimed at reducing the consumption of fossil fuels in a new or existing facility" [34], developed by the Carbon Fund for a Sustainable Economy $\left(\mathrm{FES}-\mathrm{CO}_{2}\right)$ of the Spanish Ministry of Environment, has been followed.

The methodology is based on calculating the emission reductions associated with the project as the difference between emissions from a base scenario (final energy is obtained through the burning of natural gas) and project emissions (the final energy is obtained by burning the generated methane).

\section{Results and Discussion}

\subsection{Characterization of Samples, Substrates, Inoculum and Mixtures in the Digester}

Studying the characterization of substrates, of the inoculum and from the mixture that exists in the digester, before and at the end of the BMP test, is essential to understand the development of the process and to be able to make decisions about the results obtained 
during the AD process. All tests have been conducted as described in Section 2.2, and the results are shown below.

Table 2 shows characterization results of the substrate (CrM), of the inoculum (S) and the mixture in the digester $(\mathrm{CrM}+\mathrm{S})$ before the BMP test, and after completion of the latter at 20 days. All results are indicated in the respective units, per gram of substrate, or per milliliter of sludge or reactor mix.

Table 2. Characterization results for BMP tests of residue CrM, at the start and after completion of the test.

\begin{tabular}{|c|c|c|c|c|}
\hline & $\begin{array}{c}\text { Substrate } \\
\text { Material CrM }\end{array}$ & $\begin{array}{l}\text { Inoculum } \\
\text { Material S }\end{array}$ & $\begin{array}{c}\text { Initial Reactor Mix } \\
\qquad \mathrm{CrM}+\mathrm{S}\end{array}$ & $\begin{array}{l}\text { Final Reactor Mix } \\
\qquad \mathrm{CrM}+\mathrm{S}\end{array}$ \\
\hline \multicolumn{5}{|c|}{ Physical parameters } \\
\hline Hum $[\%$ wet weight $]$ & 62.60 & 94.30 & 85.37 & 78.14 \\
\hline TS $[\%$ wet weight $]$ & 26.31 & 5.70 & 10.75 & 5.18 \\
\hline VS $[\%$ wet weight $]$ & 25.44 & 4.92 & 11.05 & 4.96 \\
\hline \multicolumn{5}{|c|}{ Macronutritional Analysis (LPCH Content) } \\
\hline Lipids (L) [\% wet weight $]$ & 0.98 & 0.47 & 0.55 & \\
\hline $\begin{array}{c}\text { Proteins }(\mathrm{P})[\% \\
\text { wet weight }]\end{array}$ & 7.37 & 0.53 & 2.25 & \\
\hline $\begin{array}{c}\text { Carbohydrates }(\mathrm{CH})[\% \\
\text { wet weight }]\end{array}$ & 77.37 & 0.56 & 19.87 & \\
\hline \multicolumn{5}{|c|}{ Organic Content Analysis (COD) } \\
\hline $\mathrm{COD}_{\mathrm{t}}\left[\mathrm{mg} \mathrm{O}_{2} / \mathrm{g}-\mathrm{mL}\right]$ & 168.80 & 101.65 & 117.52 & 105.40 \\
\hline $\mathrm{COD}_{\mathrm{f}}[\mathrm{mg} \mathrm{O} / \mathrm{g}-\mathrm{mL}]$ & 87.77 & 37.08 & 49.70 & 22.06 \\
\hline Solubility [\%] & 58.81 & 36.48 & 42.30 & 20.93 \\
\hline \multicolumn{5}{|c|}{ Nitrogen Content Analysis } \\
\hline $\mathrm{TKN}[\mathrm{mg} \mathrm{N} / \mathrm{g}-\mathrm{mL}]$ & 12.31 & 2.00 & 4.55 & 4.72 \\
\hline $\mathrm{AN}[\mathrm{mg} \mathrm{N} / \mathrm{g}-\mathrm{mL}]$ & 0.53 & 1.15 & 0.96 & 1.24 \\
\hline $\mathrm{ON}[\mathrm{mg} \mathrm{N} / \mathrm{g}-\mathrm{mL}]$ & 11.78 & 0.85 & 3.58 & 3.23 \\
\hline \multicolumn{5}{|c|}{$\mathrm{pH}$ and Alkalinity Analysis } \\
\hline $\mathrm{pH}$ & 5.22 & 7.46 & 6.85 & 6.97 \\
\hline $\begin{array}{c}\text { TA }[\mathrm{mg} \\
\left.\mathrm{CaCO}_{3} / \mathrm{g}-\mathrm{mL}\right]\end{array}$ & 5.81 & 8.88 & 8.06 & 11.06 \\
\hline $\begin{array}{c}\mathrm{PA}[\mathrm{mg} \\
\left.\mathrm{CaCO}_{3} / \mathrm{g}-\mathrm{mL}\right]\end{array}$ & - & 5.22 & 5.35 & 5.15 \\
\hline $\mathrm{IA}[\mathrm{mg} \mathrm{CaCO} / \mathrm{g}-\mathrm{mL}]$ & 5.81 & 3.65 & 2.71 & 4.47 \\
\hline \multicolumn{5}{|c|}{ Elemental Analysis } \\
\hline $\mathrm{C}[\%$ dry weight $]$ & 52.32 & 11.19 & 21.48 & \\
\hline $\mathrm{H}[\%$ dry weight $]$ & 4.43 & 9.00 & 7.75 & \\
\hline $\mathrm{N}[\%$ dry weight $]$ & 4.24 & 2.22 & 2.71 & \\
\hline $\mathrm{S}[\%$ dry weight $]$ & 0.07 & 0.18 & 0.15 & \\
\hline C/N Ratio & 12.33 & 5.04 & 7.93 & \\
\hline
\end{tabular}

CrM substrate is presented as a substrate with a high humidity level $(62.60 \%)$ which makes its solubilization, in principle, easy and the process fast and profound. If the LPCH content is compared, it is observed that it is a carbohydrate-type substrate, especially rich in simple cellulose-type carbohydrates. The digestion of this type of substrate is stable and fast, but with the likelihood of releasing VFA during its digestion from the acid digestion of monosaccharides and other simple carbohydrates. However, because of the presence of a certain protein content, a small amount of ammoniacal nitrogen is likely to be released that can compensate by acting as a buffer for the slight acidification caused by VFA. In terms of COD it is a relatively rich substrate in carbonous matter and organic matter, with a particularly high solubility (of $58.81 \%$ ), indicating that, of the entire COD, almost $60 \%$ 
is directly accessible to microorganisms without the need to hydrolyze or release from encapsulation due to being a particulate substrate. For this easy accessibility, a rapid degradation is expected, even though the inoculum is a granular UASB sludge, difficult to solubilize. In terms of nitrogen content, it is not very high. It is distributed in ON that comes from the light protein content, and in $\mathrm{AN}$, whose content is not excessive, in fact, is below the limit of accumulation studied $(2 \mathrm{~g} / \mathrm{L})$, so it is expected that the AN will be released as a buffer for $\mathrm{pH}$ control and compensate for possible acidifications, without accumulating and ending up inhibiting the process by excess ammonia in the reactor. The CrM material has a $\mathrm{C} / \mathrm{N}$ ratio of 12.33 , which is close to the optimal $\mathrm{C} / \mathrm{N}$ ratio (approx. 20 ) $[33,35,36]$ to ensure stable digestion so it is expected that the process will have alterations, but without impact, such as a release of VFA due to the carbohydrate content, compensated with a slight release of ammoniacal nitrogen that will act as buffer dampening its effect.

Analyzing changes in the composition of the mixture in the reactor, before and after the BMP test, it can be observed that the humidity has been slightly reduced, by $-8.50 \%$, which is logical when it comes to anaerobic, closed, and wet digestion digesters, as is the case of a UASB digester specially designed for liquid substrates. The reduction of vs. and TS is very remarkable, of $-51.82 \%$ and $-55.11 \%$ respectively, which gives an idea that the process has developed correctly because the organic matter present in solids form has been digested. The reduction of COD has been very low, of $-10.31 \%$, indicating that, although the digestion process has been correct, the methanization has not been completely profound (later it will be analyzed with the content in methane, since the carbon contained in the COD is the one that is transformed into methane). However, the reduction in $\mathrm{COD}_{\mathrm{f}}$ has been very noticeable, of $-55.61 \%$, indicating that, although only $10 \%$ of the COD has been reduced to be converted into methane, this has been practically a reduction in COD that is not encapsulated, and is therefore directly accessible to micro-strategies. This means that the methanization process has not been complete, by a failure of the disintegration + hydrolysis stage, which will provide a lower-than-expected methane content, below $60 \%$ which is considered the stable development limit. According to the nitrogen content, TKN is slightly increased by $3.89 \%$ by the release of some of the nitrogen encapsulated in the proteins, the ON. In fact, the ON is reduced by $-9.75 \%$ precisely by the release of this nitrogen, by degrading the proteins. For its part, the AN is increased by $28.29 \%$ when the $\mathrm{ON}$ is released, until it reaches a value of $1.24 \mathrm{mg} / \mathrm{mL}$, falling below the accumulation limit $(2 \mathrm{~g} / \mathrm{L})$ in this way it is expected that the released ammoniacal nitrogen will act as a buffer, dampening any acidification, for example, that coming from the release of VFA when digesting carbohydrates. The initial and final $\mathrm{pH}$ values are very similar; however, they are expected to have varied during the 20 days of process. As for alkalinity, TA is increased by $43.92 \%$, giving an idea of the stability of the process. Intermediate alkalinity is also increased by $64.94 \%$, indicating that either no VFA has been released, or on the contrary these have been neutralized by the buffer effect of the released AN.

All these assumptions should be checked later with the analysis of the process that develops.

\subsection{Biogas Production}

To determine biogas production, the internal pressure generated inside the digesters during the development of BMP tests is measured, and then translated into the volume of gas generated, as described in Section 2.3.

The most convenient measure to express biogas generation is gross production, that is, biogas generated by a certain amount of waste. However, several authors $[37,38]$ recommend expressing it in terms of specific production, that is, in biogas generation for each vs. containing the residue, in this way it can be compared with another substrate more quickly. Therefore, the results are commented based on gross production but are also displayed based on specific production.

As shown in Figure 1, biogas generation is completed on day 10, producing an average of $1604( \pm 19.980 \%)$ NmL of biogas measured under normal conditions, per $100 \mathrm{~g}$ of digested 
CrM residue (Table 3). Although there are some failed assays, based on the results of the ANOVA analysis developed, all curves can be considered equal and assumed by the mean curve. This is because, after performing the ANOVA analysis, the significance level is, in all curves except those that the process has been failed, 1000, so that the null assumption of average equality can be accepted, and therefore all curves equal to the mean curve can be assumed. This convergence of results was to be expected since the substrate to be treated, as advanced in Section 3.1 is a substrate rich in simple carbohydrates, which gives it the property to generate stable digestions.

Table 3. Numerical results of the BMP tests when digestion residue CrM. Gross and specific production of biogas, methane and hydrogen, methane and hydrogen content of the produced biogas and descriptive statistics.

\begin{tabular}{|c|c|c|c|c|}
\hline & $\begin{array}{c}\text { Production } \\
{[\mathrm{NmL} / \mathbf{1 0 0} \mathrm{g} \text { of residue } \mathrm{CrM}]}\end{array}$ & $\begin{array}{l}\text { Standard } \\
\text { Deviation }\end{array}$ & $\begin{array}{l}\text { Coefficient of } \\
\text { Variation }\end{array}$ & Relative Error \\
\hline Biogas & 1604.22 NmL & 525.39 & 0.32 & $19.98 \%$ \\
\hline Methane & $458.55 \mathrm{NmL}$ & 189.61 & 0.41 & $24.83 \%$ \\
\hline \multirow[t]{2}{*}{ Hydrogen } & $0.69 \mathrm{NmL}+0.33 \mathrm{NmL}$ & $0.60+0.15$ & $0.87+0.48$ & $105.72 \%+134.45 \%$ \\
\hline & $\begin{array}{c}\text { Specific Production } \\
\text { [NmL/g of vs. of residue } \\
\text { CrM] }\end{array}$ & & & \\
\hline Biogas & $63.05 \mathrm{NmL}$ & 20.65 & 0.01 & $96.53 \%$ \\
\hline Methane & $18.02 \mathrm{NmL}$ & 7.45 & 0.01 & $96.80 \%$ \\
\hline \multirow[t]{2}{*}{ Hydrogen } & $0.02 \mathrm{NmL}+0.01 \mathrm{NmL}$ & $0.02+0.02$ & $0.03+0.08$ & $92.60 \%+5.28 \%$ \\
\hline & $\begin{array}{l}\text { Content } \\
{[\% \text { vol }]}\end{array}$ & & & \\
\hline Methane & 27.48 & 7.22 & 0.26 & $16.20 \%$ \\
\hline Hydrogen & $0.28 \%+0.03 \%$ & $0.14+0.14$ & $0.43+4.37$ & $39.90 \%+349.72 \%$ \\
\hline
\end{tabular}

Figure 1 shows the average curve of all the 21 curves obtained, which can be assumed as determined by the ANOVA analysis. It can be seen in them that the initial part of the curves, there are two clearly differentiated slope changes. During the first day there is a delay, and on days 1-4 there is a linear generation, which stops until day 8-9 in which generation resumes to stabilize on day 12 . Although it will be demonstrated later in the analysis of the results of the following sections, it is an indicator that anaerobic digestion occurs in two phases. Given the characteristic particulate substrate, in the first place the organic matter is digested directly accessible, that is, the solubilized, and subsequently, after hydrolyzing the particulate matter, it begins to digest it. This assumption will be demonstrated later with the joint analysis of all the variables studied, especially with the evolution of hydrogen, as well as evolutions and compositional changes.

If the generation of biogas is compared with that obtained by the inoculum alone, the effect of adding the CrM substrate has been positive, by increasing the generation of gas by $311.33 \%$, from the $390 \mathrm{~mL}$ of biogas produced by the inoculum to the $1604.22 \mathrm{NmL}$ produced in joint digestion and by increasing the process speed, as you can see by comparing the slope of the start of the curves.

As for the specific production of biogas, the conclusions obtained are analogous to those of gross biogas production, as well as their curves, which are proportional. Specific production is nothing more than the production of biogas expressed, not by amount of gross waste, but for each gram of volatile solid contained in the residue, hence the curves are proportional. Specific production, as shown in Table 3, is estimated at 63,058 NmL of biogas per gram of vs. of CrM waste introduced into the reactor.

\subsection{Methane Production}

Figure 2 represents all the mean methane generation curves obtained during BMP tests. According to the ANOVA analysis performed, all curves can be assumed by the 
average curve, so this one will be used for the study, along with the error bars and the diagram of boxes and whiskers. The shape of the curves and the information obtained from them is similar to that obtained in biogas generation curves. Digestion occurs in the same way and clearly in two phases, and the stabilization of the process and therefore the generation of methane occurs around 10 days. In particular, the generation of methane obtained is $458.550( \pm 24.838 \%)$ Biogas NmL measured under normal conditions, per $100 \mathrm{~g}$ of digested CrM residue (Table 3).
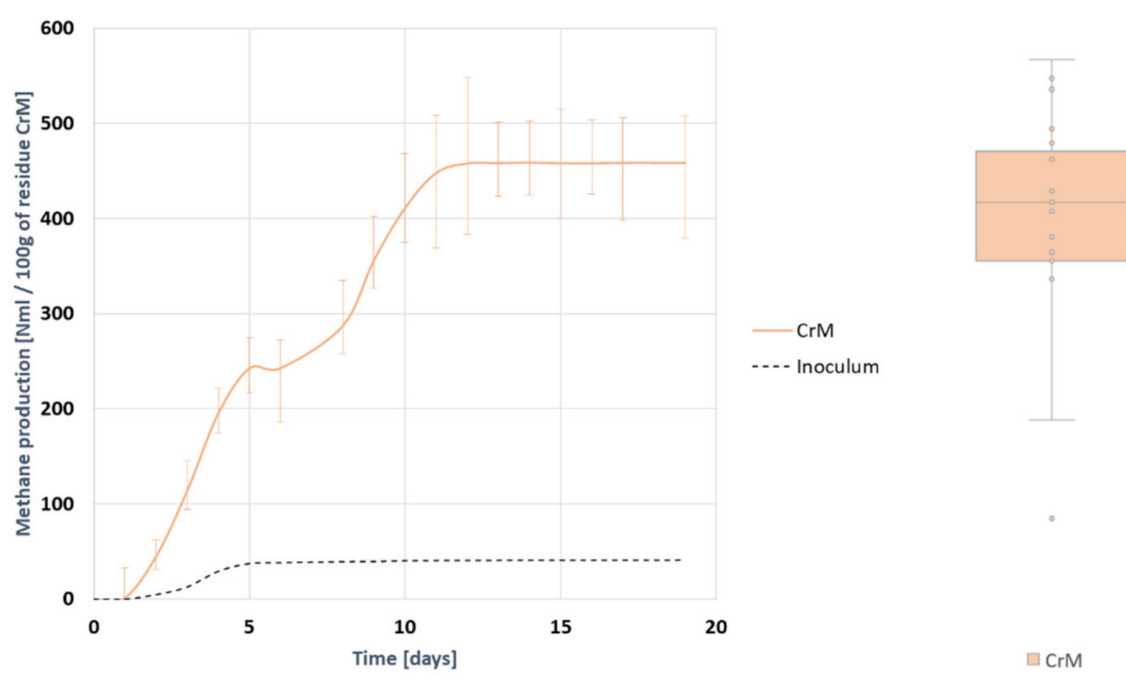

Figure 2. Gross methane production mean curve from the anaerobic digestion of $100 \mathrm{~g}$ of residue CrM and box diagram of its variation.

Although the dispersion between curves is similar to that obtained in the production of biogas, as inferred from the box and whisker diagram depicted in Figures 1 and 2 the descriptive statistics in Table 3 show that this variability between curves is not pronounced, in fact the dispersion between methane generation curves is less than the deviation between biodegradability curves or biogas production. It follows then that the process is quite stable, and the changes between them are not due to failures in the process, but to changes in the proportion of methane in biogas, which is a good indicator of the stability and development of the process and is therefore studied in a section of its own.

As for the specific production of methane, this is determined at $18.024 \mathrm{NmL}$ of methanol per gram of vs. of CrM residue introduced into the reactor.

\subsection{Methane Content of Biogas Generated}

It can be seen in Figure 3 that the proportion of methane in biogas begins to detect something before the first day, begins to grow until day 5 , slows slightly, resumes until moderately stabilized on day 10 . The curves converge around $27 \%$ of methane. This double growth and observed slope change reconfirms the two-phase digestion phenomenon that occurs, a first phase in which directly accessible organic matter is digested, and secondly particulate or encapsulated organic matter, although this must be corroborated with a somewhat more thorough analysis such as the evolution of $\mathrm{H}_{2}$ to be done in subsequent sections.

As noted, and as seen in the mean curve of Figure 4, the average methane content in the generated biogas is $27.485( \pm 16.201 \%) \%$ of $\mathrm{CH}_{4}$, resulting in an increase of $128.098 \%$ compared to the methane content of the biogas generated by the inoculum, so it is inferred again that the effect of adding CrM substrate has been positive. 


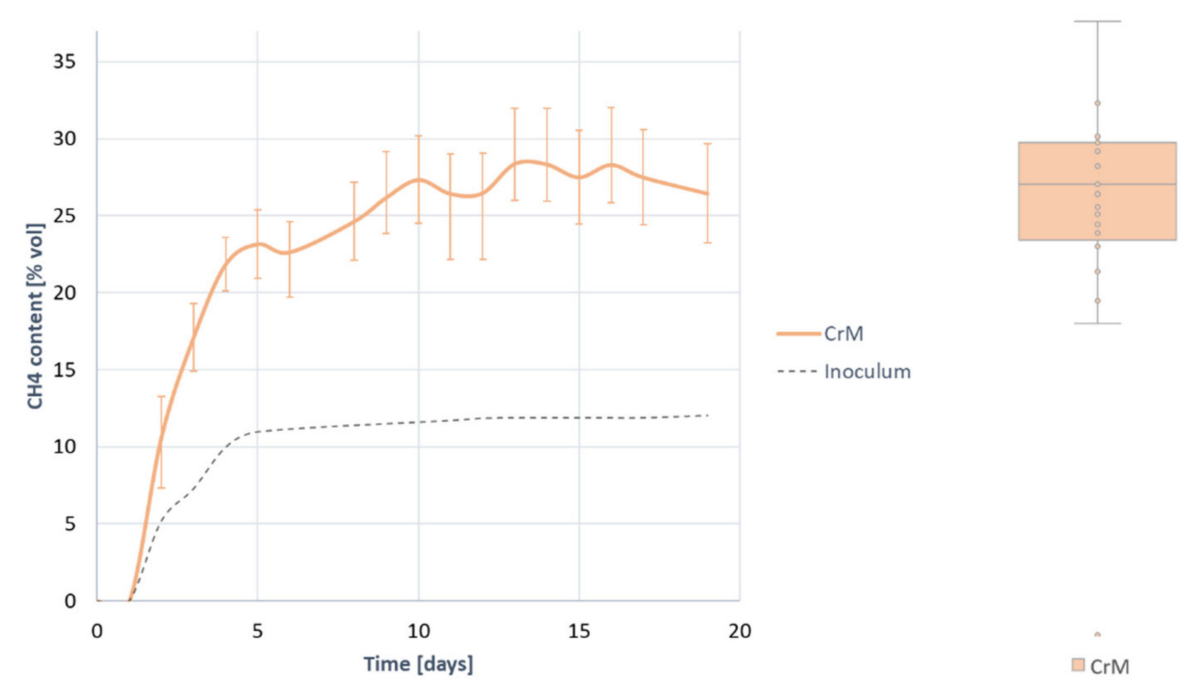

Figure 3. Methane content mean curve from the biogas produced in the anaerobic digestion of $100 \mathrm{~g}$ of residue CrM and box diagram of its variation.

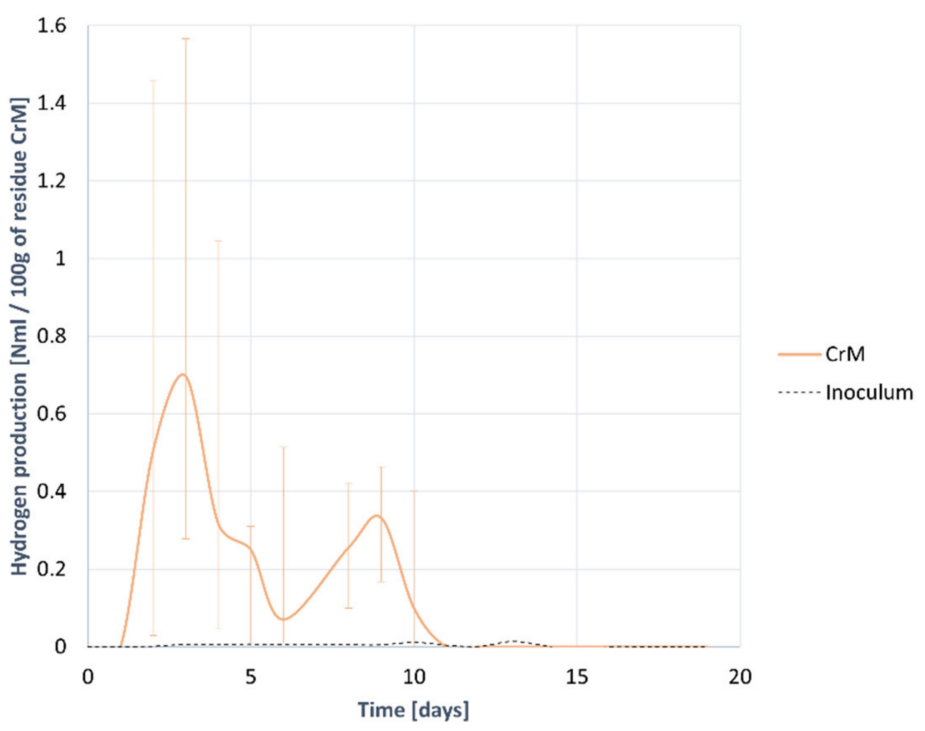

Figure 4. Gross hydrogen production mean curve from the anaerobic digestion of $100 \mathrm{~g}$ of residue $\mathrm{CrM}$.

The methane content is below $60 \%$, which is the limit considered acceptable for a stable and deeply developed process. In this case it is around $30 \%$, so the process is inferred that it is not entirely complete, as indicated in previous paragraphs and is probably due to low degradation levels, which will be demonstrated later with the mathematical analyses and determinations including the level of biodegradation of the substrate. In this case it has already been indicated that there is first digestion, only of the organic matter directly accessible or solubilized, and subsequently the encapsulation, which will logically not be digested in depth or in full (and will be determined by the analysis of the level of degradation of the substrate). Although some of the results of previous research conducted by other authors yield similar values of methane content, this study explains by the nature of the inoculum, a granular UASB substrate, specially designed to digest solubilized organic matter, and that its characteristic of granule grouping makes the hydrolysis of particulate matter complicated, since microorganisms and hydrolytic enzymes, grouped in a granule have fewer freedoms and the ability to adhere to the walls of the particulate substrate 
and start hydrolyzing it, being easier directly to act with that COD that is solubilized and directly accessible $\left(\mathrm{COD}_{\mathrm{f}}\right)$.

\subsection{Hydrogen Production}

Hydrogen generation occurs once hydrolysis has been completed and the acidic stages of acidogenesis and acetogenesis begin, which will consequently become $\mathrm{CH}_{4}$ through acetoclastic methanogenesis. Hydrogen once generated begins to disappear when it is transformed into methane using hydrogenotrophic methanogenesis. It is therefore a good indicator of process development and hydrolysis speed, although its use is not widespread as it is difficult to detect and measure against other indicators such as $\mathrm{pH}$. This research will use it for this purpose, providing added value and novelty to the study.

It is to be expected that hydrogen will form during the first few days and the larger its production and the faster the production peak is reached, the faster and deeper the hydrolysis process will be. As soon as hydrogen is generated, that is, as soon as hydrolysis is complete, the production of acidic elements by acidic elements through acidogenesis and acetogenesis begins, so it is accompanied by a decrease in $\mathrm{pH}$. When the peak is reached it is understood that hydrolysis has completed, and when it begins to disappear hydrogen it is inferred that hydrogenotrophic methanogenesis begins. Methanogenesis should also be acetoclastic, that is, it must be formed from acetic acid and acidic elements. If methanogenesis occurs correctly, hydrogen reduction (by its transformation into methane) is accompanied by an increase of $\mathrm{pH}$ (by the transformation of acidic elements into methane). Any other development with hydrogen is identified with a process failure, inhibition or stop, for example if hydrogen reduction is slowed and also coincides with a $\mathrm{pH}$ that is maintained at low levels, it is understood that there has been a build-up of acidic elements that has led to inhibition of methanogenesis, and the process has been inhibited without methane production through acetoclastic methanogenesis.

Figure 4 represents the average of gross hydrogen generation curves obtained in each BMP test, along with the error bars. The ANOVA analysis demonstrates by the level of significance that in all cases curves can be resembling the middle curve and studying the process through it.

There is a first hydrogen peak on day 3 . This means that hydrolysis ends on day 1 , and as hydrogen grows the acidic phases begin. The hydrogen generation for this peak is $0.690( \pm 105.727 \%) \mathrm{NmL}$ of hydrogen measured under normal conditions, per $100 \mathrm{~g}$ of digested CrM residue (Table 3). The variability of the data is very high, which is logical since production occurs in less than a day and many averages are performed after this period, on days 1-3. In any case, the presence of a maximum hydrogen on day 3 is clear in any test curve. From this day the amount of hydrogen begins to decrease, at a certain rate, the reduction stops between days 4 and 5 , and resumes until the 6th day. This change in slope in the reduction of $\mathrm{H}_{2}$ may be due to some kind of slowdown, which should be studied and determined with subsequent analyses, such as $\mathrm{pH}$ evolution, although it is likely to be due to an accumulation of VFA, since this substrate is prone to release them as stated in Section 3.1.

There is a second peak of $\mathrm{H}_{2}$ generation on day 9 although lower value $0.330( \pm 134.450 \%) \mathrm{NmL}$ for every $100 \mathrm{~g}$ of $\mathrm{CrM}$ residue introduced into the reactor). The appearance of this second peak may be due; well begins the digestion of particulate organic matter, which has released the components after hydrolyzing the outer membranes of the waste particles; or inhibition of methanogenesis, which subsequently resumes. Both options may be valid given the characteristics of the CrM residue studied in Section 3.1:

- CrM residue is susceptible to release VFA during digestion by having a significant carbohydrate content (although this does not seem likely due to changes occurring in AI, which does not look particularly altered and does not indicate excessive accumulation of VFA).

- $\quad$ CrM residue is strongly particulate, with resistant external membranes, especially for its content in lignocellulosic compounds. This will cause $\mathrm{COD}_{\mathrm{f}}$ to be digested at 
first, that is, The OM directly solubilized and accessible to microorganisms, and once hydrolysis has developed, the OM or COD that is encapsulated in the substrate begins to be digested.

In terms of specific production, the curves are proportional to those already described, there is a first generation peak on day 3 worth $0.027( \pm 39.903 \%) \mathrm{NmL}$ per gram if vs. of $\mathrm{CrM}$ residue introduced, and a second peak on day 9 worth $0.033( \pm 349.718 \%) \mathrm{NmL}$ for each gram of vs. of CrM waste introduced into the reactor.

\subsection{Hydrogen Content of Biogas Produced}

Like hydrogen generation, hydrogen content (Figure 5) can be used as a process indicator. Although methane is one of the final gases of $\mathrm{AD}$ and is therefore accumulated, $\mathrm{H}_{2}$ is an intermediate gas that appears and subsequently transforms into a final compound. The hydrogen ratio of the biogas generated increases in the first few days when hydrolysis, acidogenesis and acetogenesis occur, until the peak is reached as soon as the latter ends. When methanogenesis begins, the ratio of $\mathrm{H}_{2}$ should drop as hydrogen is transformed into methane by hydrogenotrophic route.

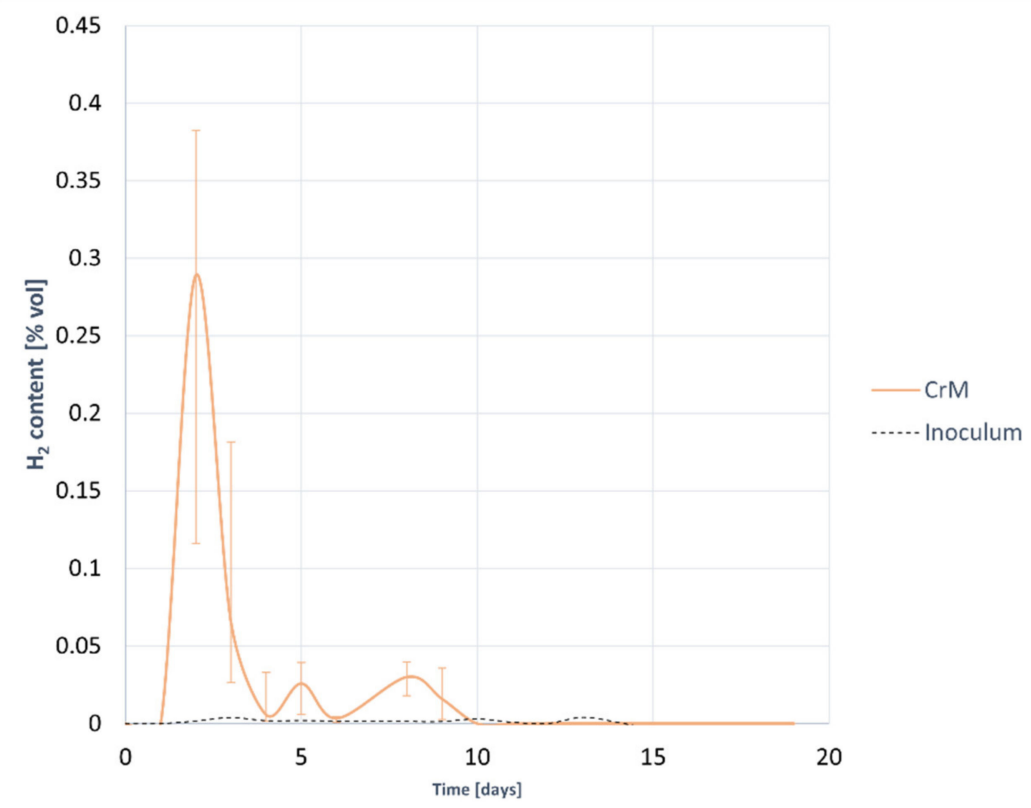

Figure 5. Hydrogen content mean curve from the biogas produced in the anaerobic digestion of $100 \mathrm{~g}$ of residue CrM.

As noted, there are the two peaks described above. The first and most pronounced occurs on day 3 with a hydrogen content of $0.289( \pm 9.903 \%) \%$, and the second occurs on day 9 reaching a hydrogen content of $0.033( \pm 349.718 \%) \%$. The occurrence of these two peaks reconfirms the possibility of two-phase digestion or a slowdown of the process that is subsequently recovered. To determine the reasons why this occurs, and to give a definitive explanation for the development of the process, we go on to study together all the generation curves together with the $\mathrm{pH}$ evolution curve, and to analyze them, taking into account the changes in the composition of the mixture at the end of the digestion process.

\subsection{Assessment of the Evolution of the Anaerobic Process}

Figure 6 represents the biogas, methane and hydrogen generation curves, along with the $\mathrm{pH}$ evolution recorded during the $\mathrm{CrM}$ residue $\mathrm{AD}$ process, and the process as a whole, can be evaluated. It is observed that: 


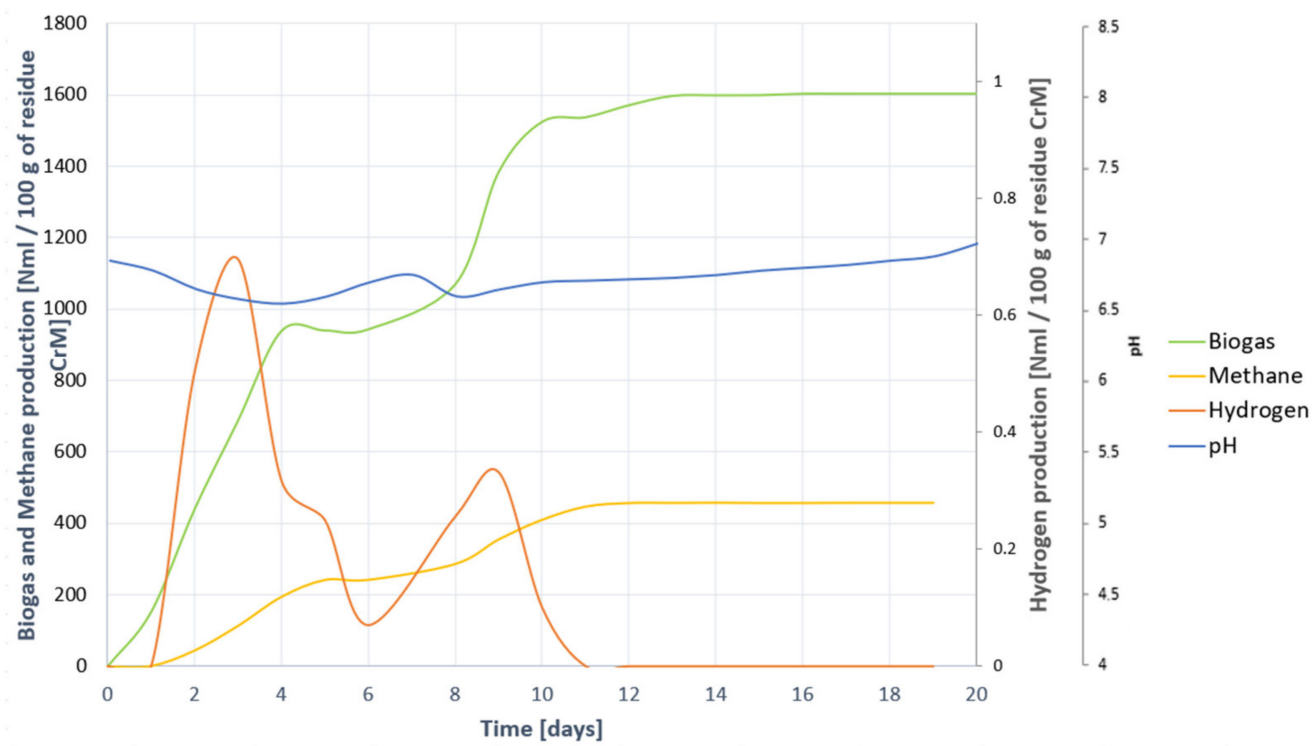

Figure 6. Evolution of the digestion process of residue CrM. Comparison of the generation of biogas, methane and hydrogen together with the evolution of $\mathrm{pH}$.

During the first day (day 0-day 1), there is a delay in the generations without a trace of methane or hydrogen, so it is assumed that the phase of disintegration + hydrolysis occurs during the first day.

Between days 1 and 3 hydrogen generation begins until it reaches a peak on day 3 . This means that during days 1 to 3 the phases of acidogenesis and acetogenesis occur. In fact, it is associated with a reduction in $\mathrm{pH}$, indicating that acidic elements such as acetic acid and VFA have formed. At that point biogas and methane begin to appear. The growth of methane is slower (with a lower slope) as it is formed only by acetoclastic route.

During days $3-4$ hydrogen disappears at a steady rate as methane and biogas continue to grow, indicating that methane is also generated by acetoclastic methanogenesis.

Between days 4 and 5 the reduction of hydrogen stops, and so do biogas and methane, so it is assumed that there is a slowdown of the process and not an inhibition, since it is subsequently resumed. In addition, being associated with a decrease in $\mathrm{pH}$ is assumed to be a slowdown by accumulation of acid elements, which is subsequently resumed when the $\mathrm{pH}$ is increased again during days 5 to 6 . This is due to the small content in AN that is released and acts as a buffer, as expected as studied in Section 3.1.

From day 6 the second peak of generation and hydrogen appears, which is accompanied by a decrease in $\mathrm{pH}$, so it is understood that the phases of acidogenesis and acetogenesis are resumed and the process of digestion resumes, In fact generations of biogas and methane are also resumed, which occurs mainly by acetoclastic route as the $\mathrm{pH}$ is increased by the transformation of the acid elements into methane.

From day 9 hydrogen reduction begins, so it is understood that hydrogenotrophic methanogenesis begins. This is confirmed by the generations of biogas and methane increasing its speed and slope, so methanogenesis is two-way, acetoclastic (pH increases) and hydrogenotrophic (hydrogen content is reduced).

On day 11 hydrogen is completely consumed, continuous methanogenesis by acetoclastic, $\mathrm{pH}$ is progressively increased to neutral values.

The process is stabilized on day 12-13 and ends without any inhibition, with correct $\mathrm{pH}$ parameters and with an evolution as expected and studied.

For all of the above, the process develops correctly, with a slight acidification by accumulation of acidic elements, but without impacts when it is dampened by the buffer effect of the AN released during the degradation of the small percentage of proteins. There are two phases of digestion, clearly identified by hydrogen peaks and the two $\mathrm{pH}$ changes. 
It is therefore assumed that during the first phase the organic matter is digested directly accessible, and during the second stage part of the non-soluble organic matter begins to hydrolyze.

\subsection{Determinations and Mathematical Adjustment of The Anaerobic Process}

Depending on the COD values determined before the BMP test and once it has been completed, therefore the degraded COD values are known, along with the values obtained in terms of methane generation, the process can be mathematically adjusted (Table 4) as studied in Section 2.5, to extrapolate and compare it with other scenarios.

Table 4. Results obtained in mathematical processing of the parameters of waste CrM biodegradation.

\begin{tabular}{lccc}
\hline & & Standard Deviation & Relative Error \\
\hline Theoretical methane generation & $487.87 \mathrm{NmL} / 100 \mathrm{~g}$ of residue CrM & 145.08 & $97.87 \%$ \\
Maximum methane & $458.82 \mathrm{NmL} / 100 \mathrm{~g}$ of residue CrM & 143.19 & $106.02 \%$ \\
generation (obtained) & 0.16 days $^{-1}$ & 0.05 & $0.03 \%$ \\
Disintegration constant & 15.28 & 2.83 & $1.91 \%$ \\
Substrate biodegradation [\%] & & & \\
\hline
\end{tabular}

Based on the initial and final COD values in the reactor mixture, the theoretical production of methane is determined, that is, what is expected to be obtained if the process had been developed correctly and all that degraded COD would have been transformed into methane. This is estimated at $487.879 \mathrm{NmL}$ of methane per $100 \mathrm{~g}$ of $\mathrm{CrM}$ residue introduced into the digester. The theoretical generation is only $6.396 \%$ higher than the average generation obtained, so it is understood that, within the degraded COD, the process has been complete since virtually all the COD consumed in methane has been transformed.

By adjusting the methane generation process to a kinetics of the first order, the maximum generation of methane obtained in all trials, quantified at $458.820( \pm 106.029 \%)$ is obtained. NmL of methane per $100 \mathrm{~g}$ of $\mathrm{CrM}$ residue, practically identical to the average generation of methane obtained. The disintegration constant, which provides information on the speed of the process and especially hydrolysis, can also be determined. In this case it is estimated at 0.164 days $^{-1}$, a fairly fast constant compared to other constants of disintegration of other elements, and that allows to compare the speed of the process with that of other substrates. This disintegration constant is an indication of the speed of hydrolysis, but not the depth of the process, for this it is necessary to go to another parameter.

It has been seen that of all the COD digested, almost everything has been transformed into methane, so the process has been robust, and has also been rapid according to the hydrolysis constant, but now arises the question of whether the process has been deep and complete, that is, whether much of the organic matter available in the substrate has been degraded in the substrate, or only a small part has been degraded. To do this, the degradation coefficient of the substrate that provides information on how much COD of the substrate has been biodegraded in the anaerobic process is analyzed. In this case it has been determined at $15.282 \%$, that is, although almost all the degraded COD has been transformed into methane, with respect to the total COD available on the CrM substrate only $15.282 \%$. This indicates that the $\mathrm{COD}_{\mathrm{f}}$ which is directly accessible to microorganisms has probably been degraded, and subsequently, in the second stage of digestion, part of the COD that is encapsulated in the substrate is digested. It should be remembered that because of its high content of hemicellulose and lignin is a particulate substrate with strong outer membranes that makes it difficult to hydrolysate and release OM. In addition, it should be borne in mind that the nature of UASB sludge is granular, specially thought for wet digestion, combining two factors, that the substrate is strongly particulate by the high content of hemicellulose and lignin, and the granular nature of the inoculum, which complicates the adhesion of hydrolytic enzymes to the substrate. These low levels of degradation would also explain the methane content below $60 \%$. These results open the 
door to process improvement through techniques such as pre-treated, which improve accessibility to the substrate, breaking the barriers created by lignocellulose and making the particulate and encapsulated COD solubilized and therefore directly accessible.

\subsection{Comparison of Results with Previous Literature}

This section compares the results obtained with some of previous research. This is intended to check whether the test conditions have been adequate, whether the use of the new process indicators can be reliable, and whether the methodology applied is valid. They also serve to leave the main innovations developed in this manuscript marked. Publications with a considerable time lapse and similar test characteristics have been selected, however they are not the same, since precisely one of the novelties introduced is the use of UASB sludge as an inoculum. The approach of most research is microbiological, not process development, so it is also another point in favor of innovation and original input.

Table 5 shows the results of other research, and in the variables that can be checked, the results are quite similar. It is then confirmed that the new methodology used can be assumed as correct, that the changes introduced are valid and that new information is provided about:

- Complete characterization of the substrate and in-depth study of the process development.

- UASB sludge can be used as a source of inoculum.

- Hydrogen is a reliable indicator of process development.

- The mathematical determinations developed are accurate and their results provide valuable information and complete the characterization of the process.

Table 5. Results obtained from bibliographic analysis, to be compared to the results of this research.

\begin{tabular}{|c|c|c|c|c|c|c|c|}
\hline \multicolumn{8}{|c|}{ Compositional Studies } \\
\hline & $\begin{array}{l}\text { TS } \\
{[\%]}\end{array}$ & $\begin{array}{l}\text { VS } \\
{[\%]}\end{array}$ & $\begin{array}{c}\mathrm{COD} * \\
{[\mathrm{mg}} \\
\left.\mathrm{O}_{2} / \mathrm{g}-\mathrm{mL}\right]\end{array}$ & $\begin{array}{c}\text { TKN * } \\
{[\mathrm{mg}} \\
\mathrm{N} / \mathrm{g}-\mathrm{mL}]\end{array}$ & $\mathrm{pH}$ & $\begin{array}{c}\mathrm{TA} * \\
{[\mathrm{mg}} \\
\left.\mathrm{CaCO}_{3} / \mathrm{g}-\mathrm{mL}\right]\end{array}$ & Reference \\
\hline Malt & 17.35 & 16.76 & 204.40 & 9.18 & 6.40 & - & {$[39,40]$} \\
\hline Malt & 25.4 & 25.0 & 168.80 & - & 5.4 & 5.50 & \\
\hline Sloe & 32.3 & 31.3 & 260.9 & - & 6 & 7.1 & {$[41]$} \\
\hline Average & 25.01 & 24.35 & 211.36 & 9.18 & 5.93 & 6.3 & \\
\hline \multicolumn{8}{|c|}{ Anaerobic digestion process in similar conditions } \\
\hline & $\begin{array}{c}\text { TS } \\
\text { removal } \\
{[\%]}\end{array}$ & $\begin{array}{r}\text { Bi } \\
{[\mathrm{NmL}}\end{array}$ & $\begin{array}{l}\text { yield * } \\
\text { r residue] }\end{array}$ & Metha & tent & $\underset{\left[\text { days }^{-1}\right]}{\mathbf{k}_{\mathrm{dis}}}$ & Reference \\
\hline Malt (35\%) & -41.1 & & & & & - & \multirow{4}{*}{ [39] } \\
\hline Malt (35\%) & -46.7 & & & & & - & \\
\hline Malt (55\%) & -54.8 & & & & & - & \\
\hline Malt (55\%) & -64.4 & & & & & - & \\
\hline Malt (1:3) & - & & & & & 0.169 & \multirow{3}{*}{ [41] } \\
\hline Malt (1:3) & - & & & & & 0.169 & \\
\hline Malt (1:3) & -69 & & & & & 0.188 & \\
\hline Average & -51.75 & & & & & 0.175 & \\
\hline
\end{tabular}

* Some of the results may vary from the literature review as they were originally expressed in different units from the ones used in this manuscript. that is, NmL per gram of volatile soled degraded (unit used in other manuscript), instead of gram of volatile solid content in the residue (unit used in this manuscript).

\subsection{Study of Full-Scale Application Potential: Energetic Feasibility and Environmental} Suitability of the Solution. Releasing Its Potential in Spain

Once the laboratory tests have been developed, the potential of the solution is studied and whether it is applicable on a real scale. To do this, a study will be carried out at the Spanish level, estimating the amount of CrM waste that is generated in each Autonomous 
Community. Subsequently, and with laboratory results, the amount of energy that is likely to be generated in each region will be estimated, and if once the needs of anaerobic reactors are met, energy is available for external use, for example for residential use, quantifying the number of homes that are estimated to be supplied. In addition, to check whether there is an environmental benefit, the reduction in emissions involved in the use of generated biogas rather than a conventional energy source such as natural gas is quantified.

\subsubsection{Estimation of CrM Waste Generation}

To estimate the amount of CrM waste generated, the statistics of the Survey on Areas and Crop Yields (ESYRCE) of the Ministry of Agriculture of Spain are thus determined the number of hectares cultivated of barley in each region, and their yield [42]. Taking into account the number of hectares of barley used for malt production, and the performance of this process, as specified in the "Guide to Technical Improvements Available in Spain of the Maltese processing sector" [43] obtains the amount of waste obtained in malting, which is identified with the CrM residue. These results are shown in Table 6, separating them by region, and next to a color scale map representing the distribution of crops in the Spanish geography.

Table 6. Estimation of CrM waste generation based on data from cultivated barley hectares from [43].

\begin{tabular}{ccc}
\hline & $\begin{array}{c}\text { Barley Cultivation } \\
\text { [kha] [43] }\end{array}$ & $\begin{array}{c}\text { CrM Generation } \\
\text { [kton] }\end{array}$ \\
\hline Andalusia & 71.7 & 18.9 \\
Asturias & 0 & 0 \\
Aragon & 373.8 & 98.7 \\
Balearic Islands & 10 & 2.6 \\
Canary Islands & 57 & 0.1 \\
Cantabria & 57 & 0.1 \\
Castile-La Mancha & 584.8 & 154.4 \\
Castile and Leon & 278 & 73.4 \\
Catalonia & 168.1 & 44.4 \\
Valencian Community & 8.5 & 2.2 \\
Extremadura & 34.3 & 9.1 \\
Galicia & 0.2 & 0.1 \\
La Rioja & 17.1 & 4.5 \\
Murcia & 24.6 & 6.4 \\
Navarre & 6.2 & 1.6 \\
Basque Country & 100.8 & 26.6 \\
\hline
\end{tabular}

\subsubsection{Estimation of Biogas and Methane Generation in Each Region}

Once estimated, CrM production is estimated at the amount of gas and methane that would be generated if this residue is digested in anaerobic digesters. For this purpose, the data obtained in the previous sections, summarized in Table 6, are used. The results of the estimation of biogas and methane for each region of the Spanish geography are shown in Table 7. Logically these results are proportional to those of the amount of CrM waste generated, and in those areas where barley production is much higher, more biogas is produced. 
Table 7. Estimation of the biogas and methane generated with the anaerobic digestion of CrM.

\begin{tabular}{ccc}
\hline & $\begin{array}{c}\text { Biogas Generation } \\
{\left[\mathbf{N m}^{3} / \text { year] }\right.}\end{array}$ & $\begin{array}{c}\text { Methane Generation } \\
{\left[\mathbf{N m}^{3} / \text { year }\right]}\end{array}$ \\
\hline Andalusia & $303,724.9$ & $83,481.8$ \\
Asturias & 0 & 0 \\
Aragon & $1,583,362.6$ & $435,203.1$ \\
Balearic Islands & $42,352.1$ & $11,640.9$ \\
Canary Islands & 242 & 66.5 \\
Cantabria & 242 & 66.5 \\
Castile-La Mancha & $2,476,991.5$ & $680,825.9$ \\
Castile and Leon & $1,177,387.7$ & $323,616.8$ \\
Catalonia & $712,119.9$ & $195,733.3$ \\
Valencian Community & $36,301.7$ & 9977.9 \\
Extremadura & $145,449.1$ & $39,978.1$ \\
Galicia & 1210.1 & 332.6 \\
La Rioja & $72,603.5$ & $19,955.8$ \\
Murcia & $104,186.1$ & $28,636.6$ \\
Navarre & $26,621.3$ & 7317.1 \\
Basque Country & $427,150.9$ & $117,406.7$ \\
Relative error & $76,959.7$ & $21,153.1$ \\
\hline
\end{tabular}

3.10.3. Estimation of the Energy Balance and Energy Available for External Uses in Each Region

The calculations in this section have been developed as explained in Section 2.6. It has been assumed that biogas is generated in anaerobic digesters of $4500 \mathrm{~m}^{3}$ capacity, and thus determine the heat and electricity needs of the installation. Once covered, it is calculated whether there is excess energy or net available energy. Figure 7 shows the amount of energy that can be extracted from the biogas generated in each region, the needs required by the installation, and the excess energy that is available for external uses. Table 8 collects all this data, determines the power of a plant equivalent to that generation and to give more applicability to the results is estimated how many homes could be sufficient in one year with the available energy.

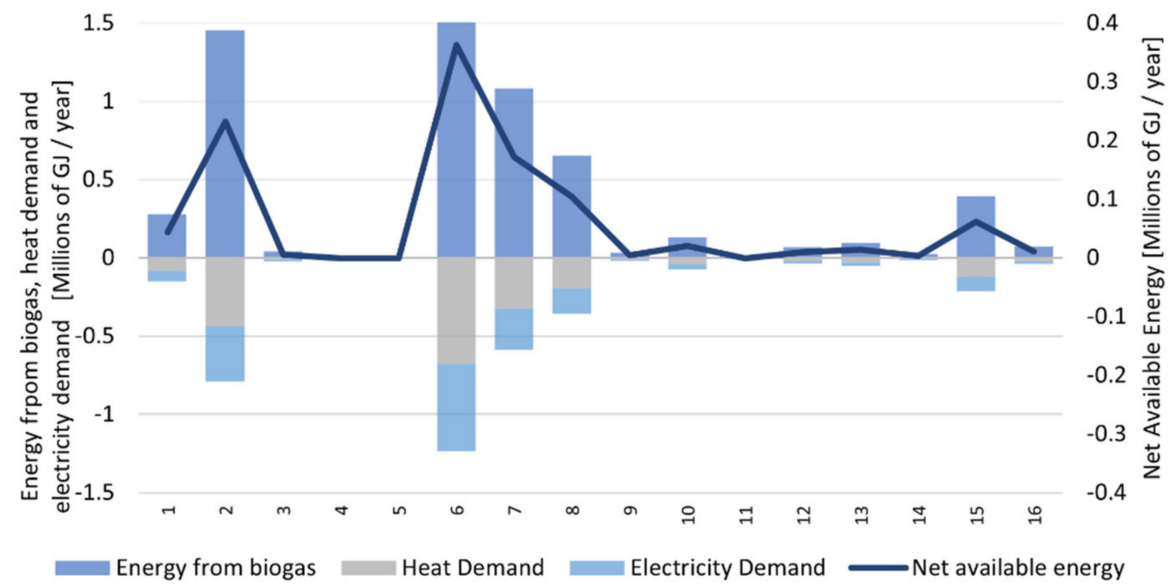

Figure 7. Energy balance of each region when treating $\mathrm{CrM}$ residue by anaerobic digestion. 
Table 8. Estimation of the energy balance of CrM's anaerobic digestion.

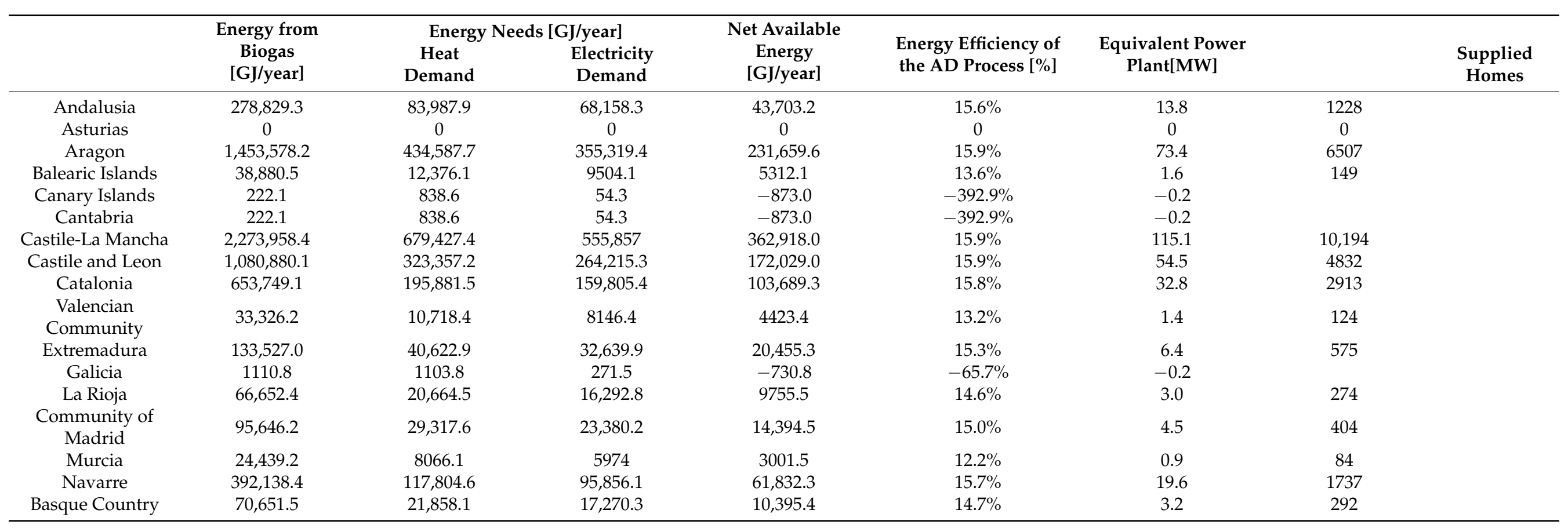


As can be observed, the region that is the most energy capable of obtaining is CastilleLa Mancha, which with this solution could become a generating power plant of $115 \mathrm{MW}$, followed by Aragon and Castile and Leon. The regions that would take the least advantage of this solution are Cantabria, Galicia and Canary Islands, which are precisely the regions that produce the least barley. Precisely for this reason the solution is not energy effective, when generating little amount of barley, the substrate level is low, little biogas is generated and is not enough to meet the needs of the reactors. The energy profitability limit can be set in the case of Murcia, that is, the solution is interesting from an energy point of view in regions that cultivate at least around 6000 hectares of barley and collect at least 1500 tons of CrM waste. As for the amount of homes that could be supplied, this solution is especially attractive for the regions with the highest available energy. For example, Castile-La Mancha could supply more than 10,000 homes in a year

This could be a solution to lack of energy supply or difficult access to energy in certain areas. The Energy Poverty report in Spain 2018 [44] of the Association of Environ-mental Sciences places the regions of Valencian Community, Murcia, Cantabria, Andalusia and Castile-La Mancha, in this order, as the areas where there is the most inequality in terms of household warming, so this solution could be of help in these regions, with the exception of Cantabria, which, as has been seen, is one of the regions in which this solution is not profitable. It is also interesting for isolated areas, such as the Balearic Islands, as it is an autonomous generation system that takes advantage of local resources.

With this proposal, renewable energy is obtained from a waste to be disposed of, thus meeting the Sustainable Development Goals (SDG) \#1 (in terms of energy poverty) \#7 on affordable and non-polluting energy, \#10 reducing inequalities in access to energy, \#12 in sustainable waste management, and \#13 of climate action by providing a renewable energy source that reduces emissions into the atmosphere, as demonstrated in the following section.

3.10.4. Estimate of the Reduction in Emissions Involved in the Use of Biogas Generated Instead of a Conventional Source of Natural Gas

Precisely, for the above reason of the impact on the SDG \#13, and since this solution fits perfectly into these goals, it is decided to study the environmental benefit that comes with, in terms of reducing $\mathrm{CO}_{2}$ emissions equivalent. The calculations have been developed in accordance with Section 2.7 of the methodology, and the results highlight the importance of the use of biogas rather than conventional sources such as natural gas.

The results are shown in Table 9, and it is confirmed that there is a $55.4 \%$ emission reduction if biogas methane is used to generate energy, rather than natural gas. Specifically, it is a reduction of 38,060 tons of $\mathrm{CO}_{2}$ equivalent at the Spanish level, being more notable in the areas where the most biogas has been generated, with Castile-La Mancha at first position.

It is important, in turn, to take into account that straws are considered biomass according to the Commission Regulation (EU) No 601/2012 of 21 June 2012 on the monitoring and reporting of greenhouse gas emissions [... ] [45], so that if they are issued in the combustion process the emissions can be considered zero, which represents a reduction in the impact of global warming in terms of the use of this fuel of $100 \%$, quantified in approximately 68,750 tons of $\mathrm{CO}_{2}$ equivalent per year less emitted into the atmosphere. 
Table 9. Estimation of the biogas and methane generated with the anaerobic digestion of CrM.

\begin{tabular}{|c|c|c|c|c|c|c|}
\hline & \multirow{2}{*}{\multicolumn{2}{|c|}{ Conventional Energy Source }} & \multirow{2}{*}{\multicolumn{2}{|c|}{$\begin{array}{l}\text { Energy from the Generated } \\
\text { Methane }\end{array}$}} & \multicolumn{2}{|c|}{$\begin{array}{l}\text { Emissions Reduction } \\
\text { [tons } \mathrm{CO}_{2} \text { eq/year] }\end{array}$} \\
\hline & & & & & & Considering \\
\hline & $\begin{array}{l}\text { Natural Gas } \\
{\left[\mathrm{Nm}^{3} / \text { year }\right]}\end{array}$ & $\begin{array}{c}\text { Emissions } \\
\text { [tons } \\
\mathrm{CO}_{2} \text { eq/year] }\end{array}$ & $\begin{array}{l}\text { Methane Gas } \\
{\left[\mathrm{Nm}^{3} / \text { year }\right]}\end{array}$ & $\begin{array}{c}\text { Emissions } \\
\text { [tons } \\
\mathrm{CO}_{2} \text { eq/year] }\end{array}$ & $\begin{array}{l}\text { Considering } \\
\text { Methane } \\
\text { Emissions }\end{array}$ & $\begin{array}{c}\text { Zero } \\
\text { Emissions } \\
\text { from Methane } \\
\text { (Biomass) }\end{array}$ \\
\hline Andalusia & $1,339,157.2$ & 2879.2 & $1,434,186.9$ & 1285.4 & -1593.8 & -2879.2 \\
\hline Asturias & 0 & 0 & 0 & 0 & 0 & 0 \\
\hline Aragon & $7,098,524.5$ & $15,262.2$ & $7,602,252.4$ & 6813.5 & -844.7 & $-15,262.2$ \\
\hline Balearic Islands & $162,775.8$ & 349.9 & $174,326.7$ & 156.2 & -193.7 & -349.9 \\
\hline Canary Islands & 0 & 0 & 0 & 0 & 0 & 0 \\
\hline Cantabria & 0 & 0 & 0 & 0 & 0 & 0 \\
\hline $\begin{array}{l}\text { Castile-La } \\
\text { Mancha }\end{array}$ & $11,120,550.8$ & $23,909.8$ & $11,909,691.1$ & 10674 & $-13,235.8$ & $-23,909.9$ \\
\hline $\begin{array}{l}\text { Castile and } \\
\text { Leon }\end{array}$ & $5,271,321$ & $11,333.6$ & $5,645,386.3$ & 5059.6 & -6274 & $-11,333.6$ \\
\hline Catalonia & $3,177,253.1$ & 6831.3 & $3,402,718.5$ & 3049.6 & -3781.6 & -6831.3 \\
\hline $\begin{array}{l}\text { Valencian } \\
\text { Community }\end{array}$ & $135,544.7$ & 291.4 & $145,163.3$ & 130.1 & -161.3 & -291.4 \\
\hline Extremadura & $626,792.9$ & 1347.6 & $671,271.6$ & 601.6 & -746 & -1347.6 \\
\hline Galicia & 0 & 0 & 0 & 0 & 0 & 0 \\
\hline La Rioja & 298,931 & 642.7 & $320,143.9$ & 286.9 & -355.8 & -642.7 \\
\hline $\begin{array}{l}\text { Community of } \\
\text { Madrid }\end{array}$ & $441,077.1$ & 948.3 & 472,377 & 423.3 & -524.9 & -948.3 \\
\hline Murcia & 91,975 & 197.7 & $98,501.8$ & 88.2 & -109.4 & -197.7 \\
\hline Navarre & $1,894,670.6$ & 4073.6 & $2,029,120.9$ & 1818.6 & -2255 & -4073.6 \\
\hline Basque Country & $318,537.4$ & 684.8 & $341,141.5$ & 305.7 & -379.1 & -684.8 \\
\hline \multicolumn{5}{|c|}{ Total reduction of emissions } & $\begin{array}{c}-38,059.6 \\
-55.3 \%\end{array}$ & $\begin{array}{c}-68,752.8 \\
-100 \%\end{array}$ \\
\hline
\end{tabular}

\section{Conclusions}

This study has determined that the composition of the CrM residue presents it as a residue formed, for the most part, by carbohydrates. It has good solubility and is relatively resistant to $\mathrm{pH}$ changes. Despite these positive aspects, its high content of hemicellulose and lignin may compromise the proper development of AD.

It has been determined that the process develops correctly, with a slight accumulation of VFA without impact when it is dampened by the buffer effect of the released AN. With the novelty introduced of the analysis of the evolution of hydrogen it has been possible to determine that the process occurs in two stages, digesting in the first stage the soluble COD, and in the second phase that of the COD that is particulate and not directly accessible. Methanization has been correct, transforming almost all the digested COD into methane. However, only $15.282 \%$ of all available COD is digested, due to the strong particulate characteristic of the substrate and the high content in lignin and hemicellulose, which makes it difficult for the for hydrolytic enzymes to adhere to particle membranes and solubilize the enclosed organic compounds; and is also due to the granular nature of the UASB inoculum. This explains why the methane content of the generated biogas is not very high.

Numerically, $100 \mathrm{~g}$ of CrM residue generates $1604.22 \mathrm{NmL}$ of biogas, with a methane content of $27.485 \%$. The disintegration constant is 0.164 days $^{-1}$ and only $15.282 \%$ of the substrate is digested. This low level of degradation opens the door to process improvement through techniques such as pre-treatments, which improve accessibility to the substrate, breaking the barriers created by lignocellulose.

As for its applicability at the national scale, it is a particularly interesting solution from the point of view of energy. It has been determined that this solution is beginning to 
be energy-effective and therefore to produce enough energy available for external uses, in areas that have at least 6000 hectares of planted barley and collect 1500 tons of CrM waste. At best, it can be considered that this solution provides, in a given region, the equivalent of a $115 \mathrm{MW}$ power plant, and could supply 10,000 households per year in that region. It is also considered an energy-efficient solution that complies with the SDGs \#1,\#7, \#10, \#12 and \#13, and can guarantee access to energy in isolated areas or with supply problems. Not only is it an energy-efficient solution, but also, in the case of SDG \#13, it has been estimated that its implementation would result in a $55.4 \%$ reduction in emissions if it were to replace a conventional natural gas energy source, reducing 38,060 tons of equivalent $\mathrm{CO}_{2}$ released into the atmosphere at Spanish level (increased to 68,750 tons if zero emissions are considered from the burning of biogas, being a form of biomass).

Author Contributions: Conceptualization, C.M.-P. and M.d.M.C.-C.; methodology, C.M.-P.; validation, M.d.M.C.-C.; formal analysis, C.M.-P.; investigation, C.M.-P., M.d.M.C.-C., M.R.-A., K.H.-K.; resources, C.M.-P., M.d.M.C.-C.; data curation, C.M.-P.; Writing-Original draft preparation, C.M.-P.; Writing-Review and editing, C.M.-P., M.d.M.C.-C.; visualization, C.M.-P., M.d.M.C.-C.; supervision, C.M.-P., M.d.M.C.-C.; project administration, C.M.-P.; funding acquisition, M.d.M.C.-C. All authors have read and agreed to the published version of the manuscript.

Funding: This research received no external funding.

Acknowledgments: Materials and equipment used for experiments were provided by Department of Mechanical Engineering. ICAI School of Engineering. Comillas Pontifical University, Madrid, Spain.

Conflicts of Interest: The authors declare no conflict of interest.

\section{Abbreviations}

$\begin{array}{ll}\text { AD } & \text { Anaerobic Digestion } \\ \text { AN } & \text { Ammoniacal Nitrogen } \\ \text { ANOVA } & \text { Analysis of Variance } \\ \text { BD } & \text { Biodegradation } \\ \text { BMP } & \text { Biochemical Methane Potential } \\ \text { CHP } & \text { Combined Heat and Power } \\ \text { COD } & \text { Chemical Oxygen Demand } \\ \text { CrM } & \text { Crop Barley Residue (Substrate) } \\ \text { CV } & \text { Coefficient of variation } \\ \text { EU } & \text { European Union } \\ \text { FAOSTAT } & \text { Statistics from the Food and Agriculture Organization of the United Nations } \\ \text { FES-CO } & \text { Carbon Fund for a Sustainable Economy } \\ \text { FSC } & \text { Food Supply Chain } \\ \text { GC } & \text { Gas Chromatograph } \\ \text { Hum } & \text { Humidity } \\ \text { IA } & \text { Intermediate Alkalinity } \\ k_{\text {dis }} & \text { Disintegration constant } \\ \text { LCFA } & \text { Long Chain Fatty Acid } \\ \text { LPCH } & \text { Lipids, Proteins and Carbohydrates content } \\ \text { OM } & \text { Organic Matter } \\ \text { ON } & \text { Organic Nitrogen } \\ \text { PA } & \text { Partial Alkalinity } \\ \text { S } & \text { Sludge (Inoculum) } \\ \text { TA } & \text { Total Alkalinity } \\ \text { TCD } & \text { Thermal Conductivity Detector } \\ \text { TKN } & \text { Total Kjeldahl Nitrogen } \\ \text { TS } & \text { Total Solids } \\ \text { UASB } & \text { Upflow Anaerobic Sludge Blanket reactor } \\ \text { VFA } & \text { Volatile Fatty Acid } \\ \text { VS } & \text { Volatile Solids } \\ \text { WWTP } & \text { Wastewater Treatment Plant } \\ & \end{array}$




\section{References}

1. EUROSTAT; FOODDRINK EUROPE. Economic Bulletin Q1 2019; EU: Brussels, Belgium, 2019.

2. EUROSTAT. Extra-EU Trade in Agricultural Goods—Statistics Explained; EU: Brussels, Belgium, 2019.

3. Database-Eurostat. Available online: https://ec.europa.eu/eurostat/data/database (accessed on 8 March 2020).

4. Chiu, S.L.H.; Lo, I.M.C. Reviewing the Anaerobic Digestion and Co-Digestion Process of Food Waste from the Perspectives on Biogas Production Performance and Environmental Impacts. Environ. Sci. Pollut. Res. 2016, 23, 24435-24450. [CrossRef] [PubMed]

5. Parfitt, J.; Barthel, M.; Macnaughton, S. Food Waste within Food Supply Chains: Quantification and Potential for Change to 2050. Philos. Trans. R. Soc. B Biol. Sci. 2010, 365, 3065-3081. [CrossRef]

6. Food and Agriculture Statisctics (FAOSTAT). Available online: http:/ /www.fao.org/statistics/en/ (accessed on 13 April 2020).

7. EUROSTAT. Agriculture, Forestry and Fishery Statistics; EU: Brussels, Belgium, 2019; ISBN 978-92-79-94757-5.

8. Buyanovsky, G.; Wagner, G. Crop Residue Input to Soil Organic Matter on Sanborn Field. In Soil Organic Matter in Temperate Agroecosystems-Long Term Experiments in North America; CRC Press: Boca Raton, FL, USA, 2019; p. 73.

9. Kumar, K.; Goh, K. Crop residues and management practices: Effects on soil quality, soil nitrogen dynamics, crop yield, and nitrogen recovery. In Advances in Agronomy; Elsevier: Amsterdam, The Netherlands, 1999; Volume 68, pp. 197-319, ISBN $0065-2113$.

10. Lal, R. The Role of Residues Management in Sustainable Agricultural Systems. J. Sustain. Agric. 1995, 5, 51-78. [CrossRef]

11. Mouratiadou, I.; Stella, T.; Gaiser, T.; Wicke, B.; Nendel, C.; Ewert, F.; van der Hilst, F. Sustainable Intensification of Crop Residue Exploitation for Bioenergy: Opportunities and Challenges. GCB Bioenergy 2020, 12, 71-89. [CrossRef]

12. De Molina, M.G.; Fernández, D.S.; Casado, G.G.; Infante-Amate, J.; Fernández, E.A.; Traver, J.V.; Ruiz, R.G. Environmental Impacts of Spanish Agriculture's Industrialization. In The Social Metabolism of Spanish Agriculture, 1900-2008; Springer: Berlin/Heidelberg, Germany, 2020; pp. 153-179.

13. Wych, R.; Rasmusson, D. Genetic Improvement in Malting Barley Cultivars Since 1920. Crop Sci. 1983, 23, 1037-1040. [CrossRef]

14. U.S. Energy Information. International Energy Outlook; U.S. Energy Information: Washington, DC, USA, 2017.

15. Aliane, A.; Abboudi, S.; Seladji, C.; Guendouz, B. An Illustrated Review on Solar Absorption Cooling Experimental Studies. Renew. Sustain. Energy Rev. 2016, 65, 443-458. [CrossRef]

16. International Energy Agency. Global Energy \& CO2 Status Report; OECD/IEA: Paris, France, 2017.

17. Ashraf, M.T.; Fang, C.; Bochenski, T.; Cybulska, I.; Alassali, A.; Sowunmi, A.; Farzanah, R.; Brudecki, G.P.; Chaturvedi, T.; Haris, S.; et al. Estimation of Bioenergy Potential for Local Biomass in the United Arab Emirates. Emir. J. Food Agric. 2016, 99-106. [CrossRef]

18. Jeguirim, M.; Limousy, L. Strategies for Bioenergy Production from Agriculture and Agrifood Processing Residues. Biofuels 2018, 9,541-543. [CrossRef]

19. De Sanctis, M.; Chimienti, S.; Pastore, C.; Piergrossi, V.; Di Iaconi, C. Energy Efficiency Improvement of Thermal Hydrolysis and Anaerobic Digestion of Posidonia Oceanica Residues. Appl. Energy 2019, 252, 113457. [CrossRef]

20. Morales-Polo, C.; Cledera-Castro, M.D.M.; Moratilla Soria, B.Y. Reviewing the Anaerobic Digestion of Food Waste: From Waste Generation and Anaerobic Process to Its Perspectives. Appl. Sci. 2018, 8, 1804. [CrossRef]

21. Morales-Polo, C.; Cledera-Castro, M.d.M.; Moratilla Soria, B.Y. Biogas Production from Vegetable and Fruit Markets WasteCompositional and Batch Characterizations. Sustainability 2019, 11, 6790. [CrossRef]

22. Gujer, W.; Zehnder, A.J.R. Conversion Processes in Anaerobic Digestion. Water Sci. Technol. 1983, 15, 127-167. [CrossRef]

23. Hawkes, F.R. The biochemistry of anaerobic digestion. In Biomethane: Production and Uses; Roger Bowskil Printing Ltd.: Exeter, UK, 1980; pp. 41-60.

24. Owens, J.M.; Chynoweth, D.P. Biochemical Methane Potential of Municipal Solid Waste (MSW) Components. Water Sci. Technol. 1993, 27, 1-14. [CrossRef]

25. VDI. VDI 4630 Fermentation of Organic Materials. Characterisation of the Substrate, Sampling, Collection of Material Data, Fermentation Tests; Verlag des Vereins Deutscher Ingenieure: Düsseldorf, Germany, 2016.

26. Elbeshbishy, E.; Nakhla, G.; Hafez, H. Biochemical Methane Potential (BMP) of Food Waste and Primary Sludge: Influence of Inoculum Pre-Incubation and Inoculum Source. Bioresour. Technol. 2012, 110, 18-25. [CrossRef] [PubMed]

27. Li, Y.; Chen, Y.; Wu, J. Enhancement of Methane Production in Anaerobic Digestion Process: A Review. Appl. Energy 2019, 240, 120-137. [CrossRef]

28. Owen, W.; Stuckey, D.; Healy, J.; Young, L.; Mccarty, P. Bioassay for Monitoring Biochemical Methane Potential and Anaerobic Toxicity. Water Res. 1979, 13, 485-492. [CrossRef]

29. Chynoweth, D.P.; Turick, C.E.; Owens, J.M.; Jerger, D.E.; Peck, M.W. Biochemical Methane Potential of Biomass and Waste Feedstocks. Biomass Bioenergy 1993, 5, 95-111. [CrossRef]

30. Granular Sludge Formation in Upflow Anaerobic Sludge Blanket (UASB) Reactors-Schmidt-1996-Biotechnology and Bioengineering-Wiley Online Library. Available online: https:/ / onlinelibrary.wiley.com/doi/abs/10.1002/(SICI)1097-0290(1996 0205)49:3\%3C229::AID-BIT1\%3E3.0.CO;2-M (accessed on 8 March 2020).

31. AENOR. UNE-EN ISO 11734:1999 Calidad Del Agua. Evaluación de La Biodegradabilidad Anaerobia "Final" de Los Compuestos Orgánicos Con Lodos En Digestión. Método Por Medida de La Producción de Biogas. (ISO 11734:1995); AENOR: Madrid, Spain, 1999.

32. Veeken, A.; Hamelers, B. Effect of Temperature on Hydrolysis Rates of Selected Biowaste Components. Bioresour. Technol. 1999, 69, 249-254. [CrossRef] 
33. Morales-Polo, C.; del Mar Cledera-Castro, M.; Hueso-Kortekaas, K.; Revuelta-Aramburu, M. Anaerobic Digestion in Wastewater Reactors of Separated Organic Fractions from Wholesale Markets Waste. Compositional and Batch Characterization. Energy and Environmental Feasibility. Sci. Total Environ. 2020, 726, 138567. [CrossRef]

34. FES-CO2; Ministerio de Alimentación y Medio Ambiente. Metodología Para Los Proyectos de Energía Térmica Destinados a La Reducción Del Consumo de Combustibles Fósiles En Una Instalación Nueva o Ya Existente; Ministerio de Alimentación y Medio Ambiente: Madrid, Spain, 2014.

35. Beniche, I.; Hungría, J.; El Bari, H.; Siles, J.A.; Chica, A.F.; Martín, M.A. Effects of C/N Ratio on Anaerobic Co-Digestion of Cabbage, Cauliflower, and Restaurant Food Waste. Biomass Conv. Bioref. 2020. [CrossRef]

36. El-Shinnawi, M.M.; El-Din, M.N.A.; El-Shimi, S.A.; Badawi, M.A. Biogas Production from Crop Residues and Aquatic Weeds. Resour. Conserv. Recycl. 1989, 3, 33-45. [CrossRef]

37. Neshat, S.A.; Mohammadi, M.; Najafpour, G.D.; Lahijani, P. Anaerobic Co-Digestion of Animal Manures and Lignocellulosic Residues as a Potent Approach for Sustainable Biogas Production. Renew. Sustain. Energy Rev. 2017, 79, 308-322. [CrossRef]

38. Schievano, A.; D’Imporzano, G.; Adani, F. Substituting Energy Crops with Organic Wastes and Agro-Industrial Residues for Biogas Production. J. Environ. Manag. 2009, 90, 2537-2541. [CrossRef]

39. Kang, H.; Weiland, P. Ultimate Anaerobic Biodegradability of Some Agro-Industrial Residues. Bioresour. Technol. 1993, 43, 107-111. [CrossRef]

40. Mohan, B.; Malleshi, N. Characteristics of Native and Enzymatically Hydrolyzed Common Wheat (Triticum Aestivum) and Dicoccum Wheat (Triticum Dicoccum) Starches. Eur. Food Res. Technol. 2006, 223, 355-361. [CrossRef]

41. De Diego-Díaz, B.; Fernández-Rodríguez, J.; Vitas, A.I.; Peñas, F.J. Biomethanization of Solid Wastes from the Alcoholic Beverage Industry: Malt and Sloe. Kinetic and Microbiological Analysis. Chem. Eng. J. 2018, 334, 650-656. [CrossRef]

42. Ministerio de Agricultura Pesca y Alimentación. Encuesta Sobre Superficies y Rendimientos Cultivos (ESYRCE). Encuesta de Marco de Áreas de España; Ministerio de Agricultura Pesca y Alimentación: Madrid, Spain, 2019.

43. Ministerio de Medio Ambiente y Medio Rural y Marino. Guía de Mejores Técnicas Disponibles en España del Sector de Elaboración de Malta; Ministerio de Medio Ambiente y Medio Rural y Marino, Centro de Publicaciones: Madrid, Spain, 2009.

44. Asociación de Ciencias Ambientales. Pobreza Energética En España 2018; Asociación de Ciencias Ambientales: Madrid, Spain, 2018.

45. The Commision of the European Communities. Commission Regulation (EU) No 601/2012 of 21 June 2012 on the Monitoring and Reporting of Greenhouse Gas Emissions Pursuant to Directive 2003/87/EC of the European Parliament and of the Council Text with EEA Relevance; EU: Brussels, Belgium, 2012. 